\title{
Synthetic 6-O-Methylglucose-containing Polysaccharides (sMGP): Design and Synthesis
}

\author{
Malte Meppen, Yonghui Wang, Hwan-Sung Cheon, and Yoshito Kishi ${ }^{*}$ \\ Department of Chemistry and Chemical Biology, Harvard University, 12 Oxford Street, Cambridge, \\ Massachusetts 02138
}

\begin{abstract}
With the hope of mimicking the chemical and biological properties of natural 6-O-methyl-Dglucose-containing polysaccharides (MGP), synthetic 6-O-methyl-D-glucose-containing polysaccharides ( $s$ MGP) were designed and synthesized from $\alpha-, \beta-$, and $\gamma$-cyclodextrins (CDs). The synthetic route proved to be flexible and general, to furnish a series of $s$ MGPs ranging from 6-mer to 20-mer. A practical and scalable method was discovered selectively to cleave the CD derivatives and furnish the linear precursors to the glycosyl donors and acceptors. The Mukaiyama glycosidation was adopted to couple the glycosyl donors with the glycosyl acceptors. Unlike in the sMMP series, an amount of the Mukaiyama acid required in the $s$ MGP series increased with an increase of substrate size; for large oligomers, more than one equivalent of the acid was required.
\end{abstract}

\section{Introduction}

In the preceding paper, ${ }^{[1]}$ we outlined the background of this research program. Briefly, Mycobacterium smegmatis is known to produce two series of polysaccharides, i.e., 3-Omethyl-D-mannose-containing polysaccharides (MMP) and 6-O-methyl-D-glucosecontaining (lipo)polysaccharides MG(L)P (Figure 1). ${ }^{[2,3,4]}$ Both MMP and MG(L)P affect profoundly the fatty acid biosynthesis catalyzed by fatty acid synthetase I (FAS I) isolated from Mycobacterium smegmatis. ${ }^{[5]} \mathrm{We}$ are interested in gaining mechanistic insights for the intriguing biological role(s) of MMP and MG(L)P. However, we felt that naturally occurring MMP and MG(L)P are not necessarily ideal substrates for our study, as they were isolated as complex mixtures of closely related polysaccharides. For this reason, we chose to use synthetic polysaccharides structurally related to natural MMP and $\mathrm{MG}(\mathrm{L}) \mathrm{P}$ for two major reasons: (1) synthetic polysaccharides should be available as the chemically well-defined and homogeneous materials and (2) synthetic polysaccharides should be structurally tunable for the needs of our investigation. Obviously, the most unique structural feature of natural MMP and MG(L)P is the polymeric form of $O$-methylated mannose and glucose. Thus, we decided to incorporate this structural feature in the synthetic polysaccharides and selected the polymers composed of 3-O-methyl-D-mannose and 6-O-methyl-D-glucose (Figure 2).

For the past one and a half decades, we have witnessed a remarkable development in chemical synthesis of oligosaccharides. A number of glycosyl donors, including halo sugars, pentenyl glycosides, thioglycosides, isopropenyl glycosides, orthoesters, 1- $O$-acyl sugars, 1-Opentenoyl sugars, trichloroacetimidates, glycosyl sulfoxides, glycosyl sulfones, glycosyl thiocyanates, glycosyl dialkylphosphites, glycosyl phosphorodithioates, glycosyl tetramethylphosphorodiamidates, glycals and 1,2-anhydrosugars, seleno glycosides, and glycosyl diazirines, are now known to effect the glycosidation in the stereoselective manner 
in solution- and/or solid-phase syntheses. ${ }^{[6]}$ Many of these synthetic methods have successfully been applied for the synthesis of a broad range of complex oligosaccharides. ${ }^{[7]}$ Related to this work, we should specifically quote the work from the Koto laboratory; they reported the synthesis of glucose-containing linear oligosaccharides having $\alpha(1 \rightarrow 4)$ and $\alpha(1 \rightarrow 6)$ linkages. ${ }^{[8]}$

With a dramatic advancement in chemical synthesis of oligosaccharides, we recognized several promising options to achieve the synthesis of 6-O-methyl-D-glucose-containing polysaccharides ( $s$ MGP). However, we opted to use the synthetic strategy reported in the preceding paper, primarily because it was proved to be effective for the case of synthetic 3$O$-methyl-D-mannose-containing polysaccharides $(s \mathrm{MMP}){ }^{[1]}$

\section{Results and Discussion}

In the preceding paper, we reported a convergent synthesis of $s \mathrm{MMP}^{[1]}$ with use of the modified Mukaiyama glycosidation. ${ }^{[9]}$ This glycosidation well suited for a highly convergent oligosaccharide synthesis, particularly because of good chemical yields even when using equalsized donors and acceptors in a molar ratio of $c a$. 1:1. The exceptionally high $\alpha / \beta$-selectivity (>50:1 > 20:1) observed in the $s$ MMP series was due to the result of the selective $\beta$-to- $\alpha$ anomerization under the Mukaiyama glycosidation conditions. Unfortunately, this beneficial anomerization was not observed in the $s$ MGP series. ${ }^{[10]}$

With this knowledge, we reevaluated the synthetic plan for $s$ MGP. As the preliminary studies suggested that the Mukaiyama glycosidation ${ }^{[9]}$ best suit for a convergent synthesis of the $s \mathrm{MMP} / s \mathrm{MGP}$ class of polysaccharides, our efforts were focused on identification of the best combination of the glucopyranosyl donor and acceptor. Using the 6- $O$-methylglucopyranosyl donors and acceptors shown in Table 1 , the $\alpha / \beta$-stereoselectivity and chemical yield were studied, thereby demonstrating: (1) the optimal protecting groups for the donor and the acceptor are benzyl and benzoate groups, respectively, and (2) the newer Mukaiyama ester and monomethyl phthalate ${ }^{[1]}$ are approximately equal, except that the glycosidation rate with the newer Mukaiyama ester ${ }^{[9 \mathrm{c}]}$ was significantly faster than that with mono-methyl phthalate.

Having identified the optimal protecting groups for the donor and acceptor, we realized that a modification should be made on the strategy used for the synthesis of $s$ MMP (Scheme 1). In the $s$ MMP series, M-a served as the source of glycosyl donor M-b and glycosyl acceptor Mc, and the donor and the acceptor were coupled under the modified Mukaiyama protocol, to furnish M-d. Importantly, except for n, M-d was identical to $\mathbf{M - a}$ and, therefore, it was not necessary to adjust the protecting groups for the next cycle. In the $s$ MGP series, however, the results summarized in Table 1 suggested that the optimal protecting groups for the donor and the acceptor are benzyl and benzoate groups, respectively, to achieve both optimal $\alpha / \beta$ stereoselectivity and chemical yield, cf., G-b and G-c. Therefore, some additional steps would be required to transform the glycosidation product G-d to the glycosyl donor and acceptor for the next cycle. cf., G-d vs. G-b and G-c. In order to avoid this potentially cumbersome adjustment of protecting groups after each cycle, we became interested in the possibility of synthesizing the glycosyl donor G-b and acceptor G-c from $\alpha-, \beta-$, and $\gamma$-cyclodextrins (CD).

CDs are naturally occurring cyclic oligosaccharides composed of $\alpha-(1 \rightarrow 4)$-linked D-glucose. $\alpha-, \beta-$, and $\gamma$-CDs contain 6-, 7-, and 8-units of $\alpha-(1 \rightarrow 4)$-linked D-glucose, respectively. Assuming that the C6 hydroxyl groups of CDs can be selectively methylated, cf. $\alpha-, \beta-$, and $\gamma$-CDs $\rightarrow \mathbf{I}$, and also that one $\alpha-(1 \rightarrow 4)$ glycosidic bond of CDs can be cleaved preferentially over the $\alpha-(1 \rightarrow 4)$ glycosidic bonds present in the cleaved products, ${ }^{[11,12]} \mathrm{cf} ., \mathbf{I} \rightarrow \mathbf{I I}$, we anticipated that the 6-,7-, and 8-mers of $\mathbf{G - b}(\mathrm{n}=6,7,8)$ and $\mathbf{G - c}(\mathrm{n}=6,7,8)$ should be 
synthesized from $\alpha-, \beta-$, and $\gamma$-CDs (Scheme 2). With this analysis, we began the experimental work on selective functionalization of CDs.

Our first task was to develop a reliable and scalable method for selective $O$-methylation of the C6 hydroxyl groups, which was achieved in four steps in excellent overall yields (Scheme 3). The selective $\mathrm{C} 6 \mathrm{O}$-silylation was reported in the literature. [11] Under the specified conditions, no scrambling of the silyl or benzoate groups were observed during benzoylation, desilylation, and $O$-methylation. ${ }^{[12,13]}$

Our second task was to develop a reliable and scalable method to selectively cleave the $\alpha$ glycosidic bond of CDs. As the cleaved product still contains 6, 7, or 8 glycosidic bonds, the proposed transformation could be problematic. Nonetheless, we hoped that the desired, first cleavage could be faster than the undesired, following cleavages, because of the ringconstraints present in protected CDs. Some examples known in the literature support the proposed step. In particular, the results reported by Kuzuhara were informative; they observed a selective cleavage of one glycosidic bond on peracylated CDs, but observed a complex product formation of permethylated CDs on acetolysis. ${ }^{[14]}$ These experiments may suggest that the presence of an electron-withdrawing protecting group is the key to achieve the desired selective hydrolysis. Indeed, the controlled acetolysis of $\mathbf{4 a \sim c}$ yielded the desired products as an approximately 6 7:1 mixture of anomeric $\alpha$ - and $\beta$-acetates. The relative rate for the first cleavage was in an order of $\mathbf{4 a}(\alpha-\mathrm{CD}$ series $)>\mathbf{4 b}(\beta-\mathrm{CD}$ series $)>\mathbf{4 c}(\gamma-\mathrm{CD}$ series $)$, and importantly the first cleavage rate was significantly faster than the following cleavages even for 4c. However, the material throughput was best achieved by quenching the acetolysis at approximately $60 \sim 70 \%$ of completion and recycling the recovered starting materials.

The next stage of synthesis was to adjust the protecting group at $\mathrm{C} 1$ of the reducing end and $\mathrm{C} 4$ of the non-reducing end. On treatment with benzylamine, the $\mathrm{C} 1$ acetate at the reducing end of 5a c was selectively hydrolyzed to yield the desired products. The resultant anomers were allylated with $\mathrm{Ag}_{2} \mathrm{O} /$ allyl bromide/DMF, furnishing the $\alpha$-allylglucosides as the major products $(\alpha: \beta$ ratio=ca. 7:1). We then ran into difficulty in selectively hydrolyzing the acetate at the non-reducing end. Selective hydrolysis of an acetate over a benzoate should not usually present a problem. However, as $\mathbf{6 a} \sim \mathbf{c}$ contained a large number of benzoates (12-, 14-, 16benzotes for $\mathbf{a}, \mathbf{b}$, and $\mathbf{c}$, respectively), it became more challenging to achieve this seemingly simple selective hydrolysis cleanly in an overall sense. Thus far, $\mathrm{HBF}_{4}$ in $\mathrm{MeOH} / \mathrm{CH}_{2} \mathrm{Cl}_{2}$ was found to give the best result. Even under this condition, it was necessary to quench the reaction at around $50 \%$ conversion to avoid the over-hydrolysis (Scheme 4).

An obvious solution to this problem was to replace the $\mathrm{C} 4$ acetyl group with a more reactive acyl group such as a trifluoroacetyl or methoxyacetyl group; the reactivity difference between $\mathrm{CF}_{3} \mathrm{CO}$ - or $\mathrm{MeOCH}_{2} \mathrm{CO}$ - over PhCO- should be more pronounced than the reactivity difference between $\mathrm{MeCO}$ - and PhCO-. Thus, we attempted to cleave the $\mathrm{CD} \mathbf{4 b}$ under a variety of conditions (Table 2). ${ }^{[15]}$ After considerable trial-and-error efforts, we finally found that $\mathrm{BF}_{3} \cdot \mathrm{Et}_{2} \mathrm{O}$-promoted cleavage of $\mathbf{4} \mathbf{b}$ in the presence of methoxyacetic acid provides an ultimate solution.

There are several appealing aspects for this cleavage reaction. First, as the reaction progressed, the cleaved product crashed out as a crystalline precipitate, recrystallization of which furnished the desired product (isolated as a 10:1 mixture of the $\alpha / \beta$-anomers) in an excellent yield. ${ }^{[16]}$ Second, this reaction was routinely run in a $5 \sim 10 \mathrm{~g}$ scale without any technical difficulty. Third and most importantly, the isolated product was shown to have the free hydroxyl group at C4 of the non-reducing end. Thus, unlike in the case of $\mathbf{6 b} \rightarrow \mathbf{7 b}$ (Scheme 4), it was unnecessary to face the problem associated with the selective hydrolysis. 
We applied the $\mathrm{BF}_{3} \cdot \mathrm{Et}_{2} \mathrm{O} / \mathrm{MeOCH}_{2} \mathrm{CO}_{2} \mathrm{H}$ conditions to the remaining $\alpha$ - and $\gamma$ - $\mathrm{CD}$ substrates. The behavior of $\gamma$-CD substrate $\mathbf{4 c}$ was found to be virtually identical to that of $\beta$-CD substrate 4b (Table 3). However, the $\alpha$-CD substrate 4a behaved differently; in the $\alpha$-CD series, the cleaved product did not precipitate out from the reaction mixture. Apparently, this difference was largely due to the solubility of products in the reaction medium. We should note that the precipitation seemed to have two additional beneficial effects, i.e., (1) the precipitation appeared to drive the cleavage reaction to completion and (2) the precipitation appeared to protect the products from further cleavage.

We conducted an optimization work on the cleavage reaction in the $\alpha$-CD series and found that the reaction rate and selectivity were greatly influenced by solvents. Among several solvents tested, $\mathrm{CH}_{2} \mathrm{Cl}_{2}$ was found to be the most effective co-solvent for acceleration of the cleavage reaction. Under the optimized conditions, the cleavage reaction proceeded smoothly to near completion and the pure product was isolated in a good yield by recrystallization (Scheme 5).

As pointed out, the linear oligomers 8a c have a free hydroxyl group at $\mathrm{C} 4$ of the non-reducing end, which facilitated the functional group manipulation required for preparation of the glycosyl acceptors and donors. The glycosyl acceptors $\mathbf{9 a} \sim \mathbf{c}$ were prepared straightforwardly from 8a $\sim \mathbf{c}$ in three steps: silylation of the $\mathrm{C} 4$ hydroxyl group at the non-reducing end, selective removal of the methoxyacetate group at $\mathrm{C} 1$ of the reducing end, and allylation of the resultant hemiacetal (Scheme 6). As described in the previous series, allylation of the resultant anomers in DMF furnished $\alpha$-allylated products with the stereoselectivity of $c a$. 7:1. Interestingly, the stereoselectivity ( $\alpha: \beta$ ratio=ca. 7:1) was reversed in allylation in dichloroethane $(\alpha: \beta$ ratio=ca. 1:6). Although we later found that the stereochemistry at the reducing end of the polysaccharides made no noticeable difference in chemical behaviors, ${ }^{[1]}$ we pursued the homogeneous material to eliminate any concerns possibly related to the stereochemistry. Separation of the mixtures was effectively achieved by Biotage flash chromatography, to afford $\alpha$-allyl acceptors with purities of $>98 \%$ in gram quantities.

The glycosyl acceptors $9 \mathbf{a} \sim \mathbf{c}$ thus obtained served as the starting materials for preparation of the glycosyl donors 12a c, which was uneventfully accomplished (Scheme 6). For the reason discussed earlier, the newer Mukaiyama ester was chosen for the activator of glycosyl donors.

The glycosidation was first attempted in the $\beta$-CD series, i.e., $\mathbf{9 b}(m=7)+\mathbf{1 2 b}(n=7) \rightarrow \mathbf{1 3 b}$ $(m+n=14)$ in Table 4. However, we soon realized that, because of poor solubility of the acceptor 9 in $\mathrm{Et}_{2} \mathrm{O}$, the glycosidation conditions optimized for model substrates (Table 1) could not be applied to this case. This difficulty was overcome by using a 1: $2 \mathrm{Et}_{2} \mathrm{O}-\mathrm{CH}_{2} \mathrm{Cl}_{2}$ mixture as the solvent, but the $\alpha / \beta$-selectivity diminished from 16:1 ( $\left.\mathrm{Et}_{2} \mathrm{O}\right)$ down to $6: 1\left(1: 2 \mathrm{Et}_{2} \mathrm{O}: \mathrm{CH}_{2} \mathrm{Cl}_{2}\right)$. Fortunately, the lowered selectivity of glycosidation did not present a technical problem, because the desired $\alpha$-isomer was least polar on silica gel TLC and readily isolable in a pure form by silica gel chromatography.

As mentioned earlier, there was one major difference recognized for the Mukaiyama glycosidation in the $s$ MGP series from that in the $s$ MMP series. Yet, we recognized another major difference; a catalytic amount $(10 \mathrm{~mol} \%)$ of the Lewis acid $\left[\mathrm{SnCl}_{3} \mathrm{ClO}_{4}\right]$ was sufficient to achieve a good conversion in the $s$ MMP series, whereas a higher loading of the catalysis seemed required to obtain a satisfactory result in the $s$ MGP series. We speculated that the lower reactivity of the glucosyl donor in the $s$ MGP series than the $s$ MMP series accounts for the differences, and conducted an optimization work. In particular, we tested higher loadings of the Mukaiyama acid. As seen from the representative examples listed in Table 4, with an increase in the size of substrates, one or more equivalents of the Mukaiyama acid was required to achieve a good conversion with satisfactory reproducibility. Unlike in the $s$ MMP series, the truncation/scrambling ${ }^{[18]}$ was negligible in the $s$ MGP series. In this series, we noticed by- 
product formation from the donors, ${ }^{[19]}$ but found that this by-product formation was significantly suppressed at $-30{ }^{\circ} \mathrm{C}$. With these modifications, we were able to achieve the glycosidation with satisfactory reproducibility.

The glycosidation products were subjected to a two-step procedure of deprotection, and the $s$ MGP 12-, 14-, and 16-mers were isolated by reverse phase column chromatography on $\mathrm{C}_{18^{-}}$ silica gel (Scheme 7). In order to assess the purity of $s \mathrm{MGP}$, extensive spectroscopic studies were conducted, thereby demonstrating that no detectable amount of $\beta$-anomer was contaminated at the newly introduced anomeric center. ${ }^{[20]}$

The successful synthesis of $s$ MGP encouraged us to explore the flexibility of the strategy for other closely related polysaccharides. First, in order to address the hydrophobic effect of polysaccharides for the complexation event with fatty acids, we pursued the synthesis of $s$ MGP analogs composed of 6- $O$-ethyl-D-glucose 14d. Gratifyingly, the same synthetic scheme as for the $s$ MGP synthesis, except for the ethylation step of the $\beta$-CD derivative $\mathbf{3 b}$, yielded the polysaccharide 14-mer, 14d (Scheme 8). ${ }^{[21,22]}$

Second, in order to test the size-effect of $s$ MGPs in the FA biosynthesis catalyzed by FAS I, we wished to have a broad range of $s$ MGPs. With use of the reported synthesis, we were able to synthesize sMGPs ranging from 6-mer to 20-mer. ${ }^{[23]}$ The case of $s$ MGP 18-mer and 20-mer summarized in Scheme 9 highlights the flexibility and usefulness of the reported synthesis.

\section{Conclusion}

An effective synthetic route to $s$ MGPs from CDs was developed. The synthetic route proved to be flexible and general, to furnish a series of $s$ MGPs ranging from 6-mer to 20-mer. A practical and scalable method was discovered selectively to cleave the CD derivatives and furnish the linear precursor to the glycosyl donors and acceptors. The Mukaiyama glycosidation was adopted to couple the glycosyl donors with the glycosyl acceptors. Unlike in the $s$ MMP series, an amount of the Mukaiyama acid required in the $s$ MGP series increased with an increase of substrate size; for large oligomers, more than one equivalent of the acid was required.

$s$ MGPs thus obtained provided us, for the first time, with an opportunity to study the chemical and biological properties of synthetic MGPs. To our delight, the preliminary experiments demonstrated that synthetic and natural MGPs exhibit the identical, or at least very similar, properties. ${ }^{[24]}$ With this encouraging result, we felt it critically important to address the scalability of $s$ MGP synthesis to ensure the supply of the materials. Recognizing a difficulty in the scalability of glycosidation, we initiated a study on the second generation of $s$ MGP synthesis, resulting in an efficient and scalable synthesis of this class of polysaccharides. ${ }^{[25]}$

\section{Experimental Section}

\section{Synthesis summarized in Scheme 3}

Transformation of $1 \mathbf{a}$ to $2 \mathbf{a}-$ To a solution of $\alpha-\mathrm{CD}(\mathbf{1 a}, 10.0 \mathrm{~g}, 10.3 \mathrm{mmol})$, dried at 90

${ }^{\circ} \mathrm{C}$ for $12 \mathrm{~h}$ under reduced pressure, in dry pyr $(200 \mathrm{~mL})$ was added TBSCl $(10.2 \mathrm{~g}, 67.8 \mathrm{mmol})$ in dry pyr $(100 \mathrm{~mL})$ dropwise at $0{ }^{\circ} \mathrm{C}$. The mixture was stirred at $\mathrm{RT}$ and the reaction was monitored by TLC every $12 \mathrm{~h}$. Additional TBSCl (up to $0.2 \times 6$ eq.) was added, if the reaction was incomplete. The excess of pyr was evaporated under reduced pressure and from the residue, white solid was precipitated out by the addition of ice-water $(300 \mathrm{~mL})$. The solid was filtered and washed with cold water $(500 \mathrm{~mL})$. The solid was taken with $\mathrm{CH}_{2} \mathrm{Cl}_{2}(300 \mathrm{~mL})$ and was washed with $1 \mathrm{~N} \mathrm{HCl}$, aq. $\mathrm{NaHCO}_{3}$, and brine. After drying over $\mathrm{Na}_{2} \mathrm{SO}_{4}$ and concentration, the product was recrystallized from EtOH (14.1 g, 83\%). 
With use of the same procedure, $\beta$ - and $\gamma$-CDs $(\mathbf{1 b}$ and $\mathbf{1 c})$ were converted to the corresponding $\mathbf{2 b}$ and $\mathbf{2 c}$, respectively. For the spectroscopic data of $\mathbf{2 a} \sim \mathbf{c}$, see Supporting Information.

Transformation of $\mathbf{2 a}$ to $\mathbf{3} \mathbf{a}-$ For the $\alpha-\mathrm{CD}$ series, the following procedure of benzoylation was used. The 6- $O$-TBS- $\alpha$-CD 2a $(14.0 \mathrm{~g}, 8.45 \mathrm{mmol})$ in pyr $(400 \mathrm{~mL})$ was cooled to $0^{\circ} \mathrm{C}$ to which was added freshly prepared BzOTf $(51.3 \mathrm{~mL}, 310 \mathrm{mmol})$ slowly. The mixture was warmed gradually to $40{ }^{\circ} \mathrm{C}$ and was stirred for $48 \mathrm{~h}$. The progress of reaction was monitored by NMR. The mixture was concentrated down to ca. $300 \mathrm{~mL}$ of pyr, to which was added aq. $\mathrm{NaHCO}_{3}(10 \mathrm{~mL})$ at $0{ }^{\circ} \mathrm{C}$ and was stirred for $10 \mathrm{~min}$. From the mixture, white solid was precipitated out by the addition of ice-water $(30 \mathrm{~mL})$ which was filtered and washed with cold water $(30 \mathrm{~mL})$. The solid was taken with $\mathrm{CH}_{2} \mathrm{Cl}_{2}(300 \mathrm{~mL})$ and was washed with $1 \mathrm{~N} \mathrm{HCl}$, aq. $\mathrm{NaHCO}_{3}$, and brine. After concentration, the product was recrystallized from EtOH (23.5 g, $95 \%)$.

Transformation of $\mathbf{2} \mathbf{b}, \mathbf{c}$ to $\mathbf{3} \mathbf{b}, \mathbf{c}-$-For the $\beta$ - and $\gamma$-CDs series, the following procedure of benzoylation was used. The 6-O-TBS- $\beta$-CD $2 \mathbf{b}(16 \mathrm{~g}, 8.3 \mathrm{mmol})$ in pyr $(500 \mathrm{~mL})$ was cooled to $0{ }^{\circ} \mathrm{C}$ to which was added $\mathrm{BzCl}(54 \mathrm{~mL}, 464 \mathrm{mmol})$ slowly. The mixture was stirred at $50^{\circ}$ $\mathrm{C}$ for 5 days. The progress of reaction was monitored by NMR. The mixture was concentrated by evaporation of pyr $(400 \mathrm{~mL})$, to which was added aq. $\mathrm{NaHCO}_{3}(100 \mathrm{~mL})$ at $0{ }^{\circ} \mathrm{C}$ and was stirred for $10 \mathrm{~min}$. From the mixture, white solid was precipitated out by the addition of icewater $(300 \mathrm{~mL})$ which was filtered and washed with cold water $(300 \mathrm{~mL})$. The solid was taken with $\mathrm{CH}_{2} \mathrm{Cl}_{2}(300 \mathrm{~mL})$ and was washed with $1 \mathrm{~N} \mathrm{HCl}$, aq. $\mathrm{NaHCO}_{3}$, and brine. After concentration, the product was recrystallized from $\mathrm{EtOH}(26 \mathrm{~g}, 93 \%)$.

For the desilylation, the following procedure used for all series. The 6-O-TBS-2,3-di- $O$ benzoyl- $\alpha$-CD thus obtained $(1.0 \mathrm{~g}, 0.34 \mathrm{mmol})$ was dissolved in $\mathrm{CH}_{3} \mathrm{CN}-\mathrm{CH}_{2} \mathrm{Cl}_{2}(20 \mathrm{~mL}$, $3: 1)$ in a plastic reactor equipped with a stirring bar. To this mixture was added $48 \%$ aq. HF $(2.0 \mathrm{~mL}, 28 \mathrm{mmol})$ slowly at RT and was stirred for $2 \mathrm{~h}$. The reaction mixture was diluted with $\mathrm{CH}_{2} \mathrm{Cl}_{2}(25 \mathrm{~mL})$ and was poured into aq. $\mathrm{NaHCO}_{3}(100 \mathrm{~mL})$. The aqueous phase was further extracted with $\mathrm{CH}_{2} \mathrm{Cl}_{2}(15 \mathrm{~mL} \times 2)$. The combined organic phase was washed with brine and dried over $\mathrm{Na}_{2} \mathrm{SO}_{4}$. The product was purified by a flash chromatography (eluent: $\mathrm{CH}_{2} \mathrm{Cl}_{2} /$ $\mathrm{MeOH})$ to give a white solid 3a $(0.63 \mathrm{~g}, 83 \%)$.

For the spectroscopic data for $\mathbf{3 a} \sim \mathbf{c}$ as well as the dibenzoates $\mathbf{2 a} \sim \mathbf{c}$, see Supporting information.

Transformation of 3a to 4a-To a solution of 2,3-di- $O$-benzoyl- $\alpha$-CD 3a ( $890 \mathrm{mg}, 0.40$ $\mathrm{mmol})$ in toluene- $\mathrm{CH}_{2} \mathrm{Cl}_{2}(40 \mathrm{~mL}, 3: 1)$ was added $\mathrm{MeI}(1.2 \mathrm{~mL}, 19 \mathrm{mmol}), \mathrm{Ag}_{2} \mathrm{O}(1.7 \mathrm{~g}, 7.2$ mmol), $\mathrm{NaHCO}_{3}(0.20 \mathrm{~g}, 2.4 \mathrm{mmol})$, and crushed $4 \mathrm{~A}$ molecular sieve ( $3.3 \mathrm{~g}$, dried). The resulting slurry was sonicated for $12 \mathrm{~h}$ and stirred for $8 \mathrm{~h}$, after which an additional portion of $\mathrm{Ag}_{2} \mathrm{O}(0.6 \mathrm{~g})$ and $4 \mathrm{~A}$ molecular sieve $(1 \mathrm{~g})$ was added. Sonication was resumed for a further 8 hours. The slurry was filtered over Celite, rinsing with $\mathrm{CH}_{2} \mathrm{Cl}_{2}$ and $\mathrm{CH}_{2} \mathrm{Cl}_{2}$-EtOAc (2:1) successively. The filtrate was reduced in vacuo and purified by a flash chromatography on silica gel (eluent: $\mathrm{CH}_{2} \mathrm{Cl}_{2} / \mathrm{EtOAc}$ ) to give the product as a white solid (790 mg, 85\%).

With use of the same procedure, $\beta$ - and $\gamma$-CDs ( $\mathbf{3 b}$ and $\mathbf{3 c}$ ) were converted to the corresponding $\mathbf{4 b}$ and $\mathbf{4 c}$, respectively.

Spectroscopic data for $\mathbf{4 a - 1}{ }^{\mathbf{1}} \mathbf{H}$ NMR $\delta 3.56(\mathrm{~s}, 3 \times 6 \mathrm{H}), 3.85(\mathrm{~d}, J=10.0 \mathrm{~Hz}, 1 \times 6 \mathrm{H})$, $4.16(\mathrm{dd}, J=11,4.0 \mathrm{~Hz}, 1 \times 6 \mathrm{H}), 4.19(\mathrm{dd}, J=8.5,8.5 \mathrm{~Hz}, 1 \times 6 \mathrm{H}), 4.50(\mathrm{dd}, J=9.5,3.5$ $\mathrm{Hz}, 1 \mathrm{H}), 5.04(\mathrm{dd}, J=11.0,4.0 \mathrm{~Hz}, 1 \times 6 \mathrm{H}), 5.44(\mathrm{~d}, J=3.5 \mathrm{~Hz}, 1 \times 6 \mathrm{H}), 6.16(\mathrm{t}, J=8.5$ $\mathrm{Hz}, 1 \mathrm{H}), 6.83(\mathrm{t}, J=8.0 \mathrm{~Hz}, 2 \times 6 \mathrm{H}), 6.90(\mathrm{t}, J=7.5 \mathrm{~Hz}, 2 \times 6 \mathrm{H}), 7.11(\mathrm{t}, J=8.0 \mathrm{~Hz}, 1 \times 6$ $\mathrm{H}), 7.15(\mathrm{t}, J=8.0 \mathrm{~Hz}, 1 \times 6 \mathrm{H}):{ }^{13} \mathbf{C}$ NMR $(100 \mathrm{MHz}): \delta 59.5 ; 71.4 ; 71.9 ; 72.2 ; 72.4 ; 78.2$; 
98.1; 127.7; 127.8; 128.3; 129.7; 130.0; 132.2; 132.6; 164.6; 166.3: MS(MALDI-TOF) calculated for $\left(\mathrm{C}_{126} \mathrm{H}_{120} \mathrm{O}_{42} \mathrm{Na}^{+}\right)$: 2327.71, found 2327.9: $[\alpha]^{25} \mathrm{D}+94.8\left(\right.$ c $\left.0.26, \mathrm{CHCl}_{3}\right)$.

Spectroscopic data for $\mathbf{4 b}-{ }^{\mathbf{1}} \mathbf{H}$ NMR $\delta 3.55(\mathrm{~s}, 3 \times 7 \mathrm{H}), 3.81(\mathrm{~d}, J=11.0 \mathrm{~Hz}, 1 \times 7 \mathrm{H})$, $4.18(\mathrm{dd}, J=9.5 \mathrm{~Hz}, 1 \times 7 \mathrm{H}), 4.22(\mathrm{dd}, J=11.0,3.5 \mathrm{~Hz}, 1 \times 7 \mathrm{H}), 4.44(\mathrm{~m}, 1 \times 7 \mathrm{H}), 5.04$

$(\mathrm{dd}, J=11.0,3,5 \mathrm{~Hz}, 1 \times 7 \mathrm{H}), 5.50(\mathrm{~d}, J=3.5 \mathrm{~Hz}, 1 \times 7 \mathrm{H}), 5.95(\mathrm{dd}, J=9.5,9.5 \mathrm{~Hz}, 1 \times 7$ H), $6.96(\mathrm{~m}, 4 \times 7 \mathrm{H}), 7.22(\mathrm{~m}, 4 \times 7 \mathrm{H}), 7.46(\mathrm{~m}, 4 \times 7 \mathrm{H}):{ }^{13} \mathbf{C}$ NMR $(100 \mathrm{MHz}): \delta 59.5$; $71.2 ; 71.6 ; 72.0 ; 76.3 ; 97.1 ; 127.8 ; 128.0 ; 128.7 ; 129.8 ; 129.95 ; 130.02 ; 132.4 ; 132.6 ; 164.7$; 166.3: MS(MALDI-TOF) calculated for $\left(\mathrm{C}_{147} \mathrm{H}_{140} \mathrm{O}_{49} \mathrm{Na}^{+}\right): 2711.84$, found 2711.8: $[\alpha]^{25} \mathrm{D}$ $+70.5\left(\right.$ c $\left.0.33, \mathrm{CHCl}_{3}\right)$.

Spectroscopic data for $\mathbf{4 c}^{\mathbf{1}}{ }^{\mathbf{H}}$ NMR $\delta 3.52(\mathrm{~s}, 3 \times 8 \mathrm{H}), 3.78(\mathrm{~d}, J=10.0 \mathrm{~Hz}, 1 \times 8 \mathrm{H})$, $4.10(\mathrm{~m}, 1 \times 8 \mathrm{H}), 4.27(\mathrm{dd}, J=9.5,9.5 \mathrm{~Hz}, 1 \times 8 \mathrm{H}), 4.32(\mathrm{~m}, 1 \times 8 \mathrm{H}), 5.07(\mathrm{dd}, J=10.5$, $3.5 \mathrm{~Hz}, 1 \times 8 \mathrm{H}), 5.54(\mathrm{~d}, J=3.5 \mathrm{~Hz}, 1 \times 8 \mathrm{H}), 5.90(\mathrm{dd}, J=8.5,8.5 \mathrm{~Hz}, 1 \times 8 \mathrm{H}), 6.99(\mathrm{t}, J$ $=8.0 \mathrm{~Hz}, 2 \times 8 \mathrm{H}), 7.07(\mathrm{t}, J=8.0 \mathrm{~Hz}, 2 \times 8 \mathrm{H}), 7.17(\mathrm{t}, J=7.15 \mathrm{~Hz}, 1 \times 8 \mathrm{H}), 7.30(\mathrm{~d}, J=7.5$ $\mathrm{Hz}, 1 \times 8 \mathrm{H}), 7.56(\mathrm{~m}, 4 \times 8 \mathrm{H}):{ }^{13} \mathbf{C}$ NMR $(100 \mathrm{MHz}): \delta 59.6 ; 70.9 ; 71.3 ; 71.8 ; 72.1 ; 74.3$; $96.2 ; 128.0 ; 128.1 ; 128.7 ; 129.7 ; 129.9 ; 130.0 ; 132.6 ; 132.8 ; 164.9 ; 166.1$ : MS(MALDITOF) calculated for $\left(\mathrm{C}_{168} \mathrm{H}_{160} \mathrm{O}_{56} \mathrm{Na}^{+}\right): 3095.96$, found 3096.1: $[\alpha]^{25} \mathrm{D}+105(c 0.26$, $\mathrm{CHCl}_{3}$ ).

\section{Synthesis summarized in Scheme 5}

Transformation of $4 \mathbf{a}$ to $8 \mathbf{a}$-To a solution of $\mathbf{4 a}(5.20 \mathrm{~g}, 2.24 \mathrm{mmol})$ in $\mathrm{CH}_{2} \mathrm{Cl}_{2}(210 \mathrm{~mL})$ at $\mathrm{RT}$ were added methoxyacetic acid $(33 \mathrm{~mL})$ and $\mathrm{BF}_{3} \cdot \mathrm{OEt}_{2}(33 \mathrm{~mL})$ and the mixture was warmed to $40{ }^{\circ} \mathrm{C}$ and was stirred for $1 \mathrm{~h}$. The mixture was diluted with $\mathrm{CH}_{2} \mathrm{Cl}_{2}$ and poured into aq. $\mathrm{NaHCO}_{3}(500 \mathrm{~mL})$. The organic phase was separated, washed with brine, dried over $\mathrm{Na}_{2} \mathrm{SO}_{4}$, and concentrated. Recrystallization from $\mathrm{MeOH}(100 \mathrm{~mL})$ afforded the ring-opened product $8 \mathbf{a}$ as a white solid $(4.50 \mathrm{~g}, 82 \%, \alpha / \beta=c a .10) .{ }^{1} \mathbf{H} \mathbf{~ N M R}(500 \mathrm{MHz})$ characteristic peaks for $\alpha$-anomer: seven methoxy- $H \delta 3.30(\mathrm{~s}, 3 \mathrm{H}), 3.35(\mathrm{~s}, 3 \mathrm{H}), 3.37(\mathrm{~s}, 3 \mathrm{H}), 3.40(\mathrm{~s}, 3 \mathrm{H}), 3.45$ $(\mathrm{s}, 3 \mathrm{H}), 3.47(\mathrm{~s}, 3 \mathrm{H}), 3.55(\mathrm{~s}, 3 \mathrm{H})$; the reducing end anomeric $-H$ : $6.57(\mathrm{~d}, J=3.4 \mathrm{~Hz}, 1 \mathrm{H})$; MS(MALDI-TOF) calculated for $\left(\mathrm{C}_{129} \mathrm{H}_{126} \mathrm{O}_{45} \mathrm{Na}^{+}\right): 2417.74$, found $2418.0 ;[\alpha]^{25}{ }_{\mathrm{D}}+78.1$ (c $0.43, \mathrm{CHCl}_{3}$ ).

Transformation of $\mathbf{4 b}$ to $\mathbf{8 b}$-Into a $1 \mathrm{~L}$ flask containing $\mathbf{4 b}(6.00 \mathrm{~g}, 2.20 \mathrm{mmol})$ and a stirring bar was added a mixture of methoxyacetic acid $(250 \mathrm{~mL})$ and $\mathrm{BF}_{3} \cdot \mathrm{OEt}_{2}(47 \mathrm{~mL})$ at RT. After approximately $2 \mathrm{~h}$ of stirring, the starting material dissolved completely, followed by appearance of a white precipitated after about $5 \mathrm{~h}$ and was stirred further for $18 \mathrm{~h}$. Then cold water $(300 \mathrm{~mL})$ was added to the reaction mixture. The white precipitate was filtered and washed with water $(3 \times 100 \mathrm{~mL})$. The solid was taken up with $\mathrm{CH}_{2} \mathrm{Cl}_{2}(200 \mathrm{~mL})$ and washed with aq. $\mathrm{NaHCO}_{3}(2 \times 100 \mathrm{~mL})$, and brine $(100 \mathrm{~mL})$. After drying over $\mathrm{Na}_{2} \mathrm{SO}_{4}$ and concentration, recrystallization from EtOAc/hexanes gave $\mathbf{8 b}$ as a white solid $(5.44 \mathrm{~g}, 88 \%$, $\alpha / \beta=c a .3) .{ }^{1} \mathbf{H}$ NMR $(500 \mathrm{MHz})$ characteristic peaks for $\alpha$-anomer: eight methoxy- $H: \delta 3.30$ (s, $3 \mathrm{H}), 3.32$ (s, $3 \mathrm{H}), 3.35$ (s, $3 \mathrm{H}), 3.37$ (s, $3 \mathrm{H}), 3.40$ (s, $3 \mathrm{H}), 3.45$ (s, $3 \mathrm{H}), 3.47$ (s, $3 \mathrm{H})$, $3.55(\mathrm{~s}, 3 \mathrm{H})$, the reducing end anomeric $-H$ : $6.57(\mathrm{~d}, J=3.4 \mathrm{~Hz}, 1 \mathrm{H})$; MS(MALDI-TOF) calculated for $\left(\mathrm{C}_{150} \mathrm{H}_{146} \mathrm{O}_{52} \mathrm{Na}^{+}\right)$: 2801.87, found 2801.9; $[\alpha]^{25} \mathrm{D}+75.6\left(c 0.31, \mathrm{CHCl}_{3}\right)$.

Transformation of $\mathbf{4 c}$ to $\mathbf{8 c}-$ Following the procedure given for $\mathbf{4 b} \rightarrow \mathbf{8 b}, \mathbf{4 c}(3.80 \mathrm{~g}, 12.5$ mmol) was converted to $8 \mathbf{c}(3.46 \mathrm{~g}, 88 \%, \alpha / \beta=c a$. 2$) .{ }^{\mathbf{1}} \mathbf{H ~ N M R}(500 \mathrm{MHz})$ characteristic peaks for $\alpha$-anomer: $\delta 3.30(\mathrm{~s}, 3 \mathrm{H}), 3.32(\mathrm{~s}, 3 \mathrm{H}), 3.33(\mathrm{~s}, 3 \mathrm{H}), 3.34(\mathrm{~s}, 3 \mathrm{H}), 3.35(\mathrm{~s}, 3 \mathrm{H}) 3.41(\mathrm{~s}$, $3 \mathrm{H}), 3.47(\mathrm{~s}, 3 \mathrm{H}), 3.49(\mathrm{~s}, 3 \mathrm{H}), 3.57(\mathrm{~s}, 3 \mathrm{H})$, the reducing end anomeric $-H: 6.57(\mathrm{~d}, J=3.4$ $\mathrm{Hz}, 1 \mathrm{H})$; MS(MALDI-TOF) calculated for $\left(\mathrm{C}_{171} \mathrm{H}_{166} \mathrm{O}_{59} \mathrm{Na}^{+}\right)$: 3185.99 , found 3185.9; $[\alpha]^{25} \mathrm{D}+77.2\left(c 0.33, \mathrm{CHCl}_{3}\right)$. 


\section{Synthesis summarized in Scheme 6}

Transformation of $8 \mathbf{a}$ to $9 \mathbf{a}-\mathrm{To}$ a solution of $\mathbf{8 a}(4.50 \mathrm{~g}, 1.89 \mathrm{mmol})$ and $\mathrm{Et}_{3} \mathrm{~N}(1.7 \mathrm{~mL}$, $11.4 \mathrm{mmol})$ in $\mathrm{CH}_{2} \mathrm{Cl}_{2}(100 \mathrm{~mL})$ at $0^{\circ} \mathrm{C}$ was added and TMSOTf $(1.05 \mathrm{~mL}, 5.67 \mathrm{mmol})$ slowly. The solution was gradually warmed to RT and was stirred for $1 \mathrm{~h}$. Work-up with $\mathrm{CH}_{2} \mathrm{Cl}_{2} / \mathrm{aq}$. $\mathrm{NaHCO}_{3}$. The crude product was recrystallized from EtOAc/hexanes to give the TMS-ether of $\mathbf{8 a}$ as a white solid $(4.40 \mathrm{~g}, 96 \%)$.

To a solution of the TMS-ether of $\mathbf{8 a}(4.28 \mathrm{~g}, 1.73 \mathrm{mmol})$ in $\mathrm{CH}_{2} \mathrm{Cl}_{2}(60 \mathrm{~mL})$ was added ethanolamine $(1.04 \mathrm{~mL}, 17.3 \mathrm{mmol})$ at $\mathrm{RT}$ and the mixture was stirred for $5 \mathrm{~h}$. The reaction mixture was diluted with $\mathrm{CH}_{2} \mathrm{Cl}_{2}(50 \mathrm{~mL})$, poured into water $(100 \mathrm{~mL})$, and partitioned. The organic phase was washed with brine and dried over $\mathrm{Na}_{2} \mathrm{SO}_{4}$. Flash chromatography (eluent: $\left.\mathrm{CH}_{2} \mathrm{Cl}_{2} / \mathrm{EtOAc}\right)$ yielded the glycoside $(3.85 \mathrm{~g}, 92 \%, \alpha / \beta=c a .2)$.

9a ( $\alpha$-anomer enriched)-To a solution of the glycoside thus obtained $(2.00 \mathrm{~g}, 0.842 \mathrm{mmol}$ ) in DMF $(60 \mathrm{~mL})$ were added $\mathrm{Ag}_{2} \mathrm{O}(1.56 \mathrm{~g}, 6.47 \mathrm{mmol})$, crushed 4A MS (activated, $2.0 \mathrm{~g}$ ), allyl bromide $(0.73 \mathrm{~mL}, 8.42 \mathrm{mmol})$, and $\mathrm{NaHCO}_{3}(0.42 \mathrm{~g}, 5.05 \mathrm{mmole})$. The dark suspension was stirred for $18 \mathrm{~h}$. The slurry was filtered over Celite, rinsing with $\mathrm{CH}_{2} \mathrm{Cl}_{2}$ and $\mathrm{CH}_{2} \mathrm{Cl}_{2}$ EtOAc (2:1) successively. The filtrate was reduced in vacuo and purified by flash chromatography on silica gel (eluent: $\mathrm{CH}_{2} \mathrm{Cl}_{2} / \mathrm{EtOAC}$ ) to give the product $9 \mathbf{a}$ as a white solid $(2.03 \mathrm{~g}, 92 \%, \alpha / \beta=c a .7)$. The anomeric mixture $(1.5 \mathrm{~g})$ was loaded on loaded on a Biotage ${ }^{\circledR}$ column $(40+\mathrm{M}, \varphi=4.0 \mathrm{~cm})$, and was eluted by $\mathrm{EtOAc} / \mathrm{CHCI}_{3}$ with a linear gradient from $4 \%$ to $20 \%$ (1.2 L), to furnish the $\alpha$-anomer $(1.0 \mathrm{~g}, \alpha: \beta=c a .100: 1)$ and the $\beta$-enriched anomeric mixture (0.34 g, $\alpha / \beta=c a .1: 2)$. Spectroscopic data for 9a $(\alpha: \beta=c a .100: 1):{ }^{1} \mathbf{H}$ NMR $(500 \mathrm{MHz})$ characteristic peaks for $\alpha$-anomer: TMS- $H$ : $\delta-0.02(\mathrm{~s}, 9 \mathrm{H})$; six methoxy- $H$ : $3.30(\mathrm{~s}, 3 \mathrm{H}), 3.33$ $(\mathrm{s}, 3 \mathrm{H}), 3.35(\mathrm{~s}, 3 \mathrm{H}), 3.44(\mathrm{~s}, 3 \times 2 \mathrm{H}), 3.56(\mathrm{~s}, 3 \mathrm{H})$; the reducing end anomeric $-H$ : $5.26(\mathrm{~d}$, $J=3.4 \mathrm{~Hz}, 1 \mathrm{H})$; MS(MALDI-TOF) calculated for $\left(\mathrm{C}_{132} \mathrm{H}_{134} \mathrm{O}_{43} \mathrm{SiNa}^{+}\right): 2457.80$, found $2457.9 ;[\alpha]^{25} \mathrm{D}+68.8\left(c 0.28, \mathrm{CHCl}_{3}\right)$.

Transformation of $\mathbf{8 b}, \mathbf{c}$ to $9 \mathrm{~b}, \mathrm{c}-$-Using the same procedure, $8 \mathrm{~b}$ and $\mathbf{c}$ were converted to $9 \mathbf{b}$ and $\mathbf{c}$, respectively. The $\alpha$-enriched $9 \mathbf{b}$ and $9 \mathbf{c}(\alpha / \beta=c a$. 100:1) were obtained by using the same chromatographic method.

Spectroscopic data for 9b ( $\alpha$-anomer enriched)—TMS- $H$ : $\delta 0.00$ (s, $9 \mathrm{H}$ ); seven methoxy-H: $3.30(\mathrm{~s}, 3 \times 3 \mathrm{H}), 3.31(\mathrm{~s}, 3 \mathrm{H}), 3.34(\mathrm{~s}, 3 \mathrm{H}), 3.44(\mathrm{~s}, 3 \times 2 \mathrm{H}), 3.56(\mathrm{~s}, 3 \mathrm{H})$; the reducing end anomeric $-H: 5.26(\mathrm{~d}, J=3.4 \mathrm{~Hz}, 1 \mathrm{H})$; MS (MALDI-TOF) calculated for $\left(\mathrm{C}_{153} \mathrm{H}_{154} \mathrm{O}_{50} \mathrm{SiNa}^{+}\right): 2841.92$, found: $2881.9 ;[\alpha]^{25} \mathrm{D}+76.4\left(c \mathrm{c} 0.38, \mathrm{CHCl}_{3}\right)$.

Spectroscopic data for 9c ( $\alpha$-anomer enriched)-1 ${ }^{\mathbf{1}} \mathbf{H}$ NMR characteristic peaks for $\alpha$-anomeric-OH product: 4-OTMS- $H$ : $\delta$ - 0.02 (s, $9 \mathrm{H})$; eight methoxy- $H$ : $3.29(\mathrm{~s}, 3 \mathrm{H}), 3.30$ $(\mathrm{s}, 3 \times 3 \mathrm{H}), 3.34(\mathrm{~s}, 3 \mathrm{H}), 3.44(\mathrm{~s}, 3 \times 2 \mathrm{H}), 3.56(\mathrm{~s}, 3 \mathrm{H})$; the reducing end anomeric $-H: 5.25$ $(\mathrm{d}, \mathrm{J}=3.4 \mathrm{~Hz}, 1 \mathrm{H}) ;(\mathrm{d}, J=8.0 \mathrm{~Hz}, 1 \mathrm{H})$; MS (MALDI-TOF) calculated for $\left(\mathrm{C}_{153} \mathrm{H}_{154} \mathrm{O}_{50} \mathrm{SiNa}^{+}\right)$: 3226.04 , found: $3226.0 ;[\alpha]^{25} \mathrm{D}+78.0\left(c 0.45, \mathrm{CHCl}_{3}\right)$.

Transformation of 9a c to $10 a \sim c-T h e$ following procedure was applied for all series. To $9 \mathbf{a}(1.65 \mathrm{~g}, 0.677 \mathrm{mmol})$ was added mixture of $1 \mathrm{~N} \mathrm{HCl} /$ acetone $(40 \mathrm{~mL}, 1: 9)$ and the mixture was stirred at $\mathrm{RT}$ for $1 \mathrm{~h}$. Then the mixture was reduced in vacuo and the residue was taken with $\mathrm{CH}_{2} \mathrm{Cl}_{2}(50 \mathrm{~mL})$ and washed with $\mathrm{NaHCO}_{3}$ and brine successively. After drying over $\mathrm{Na}_{2} \mathrm{SO}_{4}$, solvents of the organic phase were exchanged with $\mathrm{CH}_{2} \mathrm{Cl}_{2}-\mathrm{CH}_{3} \mathrm{OH}(30-15 \mathrm{~mL})$.

To the resultant residue was added $\mathrm{NaOMe}(400 \mathrm{mg}, 7.40 \mathrm{mmol})$. The mixture was stirred at $\mathrm{RT}$ for $22 \mathrm{~h}$ and then evaporated to dryness. 
To the resultant residue were added THF (40 mL), DMF (10 mL), NaH (95\%, $602 \mathrm{mg}, 24.0$ $\mathrm{mmol}$ ), and TBAI ( $250 \mathrm{mg}, 0.677 \mathrm{mmol}$. The heterogeneous mixture was stirred at RT for 30 min before benzyl bromide $(3.13 \mathrm{~mL}, 26.4 \mathrm{mmol})$ was added. The mixture was stirred at RT for $21 \mathrm{~h}$. After quenched by $5 \mathrm{~mL}$ of methanol at $0{ }^{\circ} \mathrm{C}$, the mixture was taken with $\mathrm{CH}_{2} \mathrm{Cl}_{2}$ $(100 \mathrm{~mL})$ and rinsed with $1 \mathrm{~N} \mathrm{HCl}$, aq. $\mathrm{NaHCO}_{3}$, and brine. Flash chromatography on silica gel (eluent: benzene/EtOAc) afforded 10a $(1.20 \mathrm{~g}, 77 \%) .{ }^{\mathbf{1}} \mathbf{H}$ NMR $(500 \mathrm{MHz})$ characteristic peaks for $\alpha$-anomer: six methoxy- $H$ : $\delta 3.29(\mathrm{~s}, 3 \mathrm{H}), 3.31(\mathrm{~s}, 3 \mathrm{H}), 3.32(\mathrm{~s}, 3 \mathrm{H}), 3.33(\mathrm{~s}, 3 \mathrm{H})$, $3.37(\mathrm{~s}, 3 \mathrm{H}), 3.42(\mathrm{~s}, 3 \mathrm{H})$; allyl- $\mathrm{CH}_{2}: 5.22(\mathrm{dd}, J=11.0,1.5 \mathrm{H}, 1 \mathrm{H}), 5.36 \mathrm{dd}, J=17.0,1.5$ $\mathrm{Hz}, 1 \mathrm{H})$; six a-anomeric- $H$ : $5.60(\mathrm{~d}, J=4.0 \mathrm{~Hz}, 1 \mathrm{H}), 5.63(\mathrm{~d}, J=3.5 \mathrm{~Hz}, 1 \mathrm{H}), 5.68(\mathrm{~m}, 4$ $\mathrm{H}$ ); MS (MALDI-TOF) calculated for $\left(\mathrm{C}_{136} \mathrm{H}_{160} \mathrm{O}_{34} \mathrm{Na}^{+}\right)$: 2308.05, found: $2307.9 ;[\alpha]^{25} \mathrm{D}$ $+72.0\left(\right.$ c $\left.0.23, \mathrm{CHCl}_{3}\right)$.

Spectroscopic data for $\mathbf{1 0 b}-{ }^{\mathbf{1}} \mathbf{H}$ NMR $(500 \mathrm{MHz})$ characteristic peaks for $\boldsymbol{\alpha}$-anomer: seven methoxy- $H$ : $\delta 3.29(\mathrm{~s}, 3 \mathrm{H}), 3.30(\mathrm{~s}, 3 \mathrm{H}), 3.32(\mathrm{~s}, 3 \mathrm{H}), 3.33(\mathrm{~s}, 3 \mathrm{H}), 3.37(\mathrm{~s}, 3 \mathrm{H}), 3.39$ $(\mathrm{s}, 3 \mathrm{H}), 3.42(\mathrm{~s}, 3 \mathrm{H})$; allyl-CH $2: 5.22(\mathrm{dd}, J=11.0,1.5 \mathrm{H}, 1 \mathrm{H}), 5.36(\mathrm{dd}, J=17.0,1.5 \mathrm{~Hz}$, $1 \mathrm{H})$; seven $\alpha$-anomeric- $H$ : $5.60(\mathrm{~d}, J=4.0 \mathrm{~Hz}, 1 \mathrm{H}), 5.63(\mathrm{~d}, J=3.5 \mathrm{~Hz}, 1 \mathrm{H}), 5.68(\mathrm{~m}, 5 \mathrm{H})$; MS (MALDI-TOF) calculated for $\left(\mathrm{C}_{157} \mathrm{H}_{180} \mathrm{O}_{36} \mathrm{Na}^{+}\right)$: 2664.21, found: 2664.3 ; $[\alpha]^{25} \mathrm{D}+75.3$ (c $\left.0.15, \mathrm{CHCl}_{3}\right)$.

Spectroscopic data for $\mathbf{1 0 c}^{\mathbf{1}} \mathbf{H}$ NMR $(500 \mathrm{MHz})$ characteristic peaks for $\alpha$-anomer: eight methoxy- $H$ : $\delta 3.29(\mathrm{~s}, 3 \mathrm{H}), 3.30(\mathrm{~s}, 3 \mathrm{H}), 3.316(\mathrm{~s}, 3 \mathrm{H}), 3.322(\mathrm{~s}, 3 \mathrm{H}) 3.36(\mathrm{~s}, 3 \mathrm{H}), 3.37$ (s, $3 \mathrm{H}), 3.39$ (s, $3 \mathrm{H}), 3.42(\mathrm{~s}, 3 \mathrm{H})$; allyl-C $H_{2}: 5.21(\mathrm{dd}, J=11.0,1.5 \mathrm{H}, 1 \mathrm{H}), 5.36(\mathrm{dd}, J$ $=17.0,1.5 \mathrm{~Hz}, 1 \mathrm{H})$; eight a-anomeric- $H: 5.59(\mathrm{~d}, J=3.5 \mathrm{~Hz}, 1 \mathrm{H}), 5.64(\mathrm{~d}, J=3.5 \mathrm{~Hz}, 1 \mathrm{H})$, $5.67(\mathrm{~m}, 6 \mathrm{H})$; MS (MALDI-TOF) calculated for $\left(\mathrm{C}_{178} \mathrm{H}_{204} \mathrm{O}_{41} \mathrm{Na}^{+}\right)$: 3020.38, found: 3020.1; $[\alpha]^{25}+68.3\left(c 0.43, \mathrm{CHCl}_{3}\right)$.

Transformation of $10 \mathrm{a} \sim \mathrm{c}$ to $11 \mathrm{a} \sim \mathrm{c}-$ The following procedure was applied for all series. To a solution of 10a $(0.80 \mathrm{~g}, 0.35 \mathrm{mmol})$ in EtOH-toluene $(6-3 \mathrm{~mL})$ were added $\left(\mathrm{Ph}_{3} \mathrm{P}\right)_{3} \mathrm{RhCl}$ $(16 \mathrm{mg}, 0.018 \mathrm{mmol})$ and DABCO $(5.9 \mathrm{mg}, 0.053 \mathrm{mmol})$. The mixture was heated at $80{ }^{\circ} \mathrm{C}$ for $20 \mathrm{~h}$. After the removal of solvents, the residue was stirred with $1 \mathrm{~N} \mathrm{HCl}$-acetone $(1: 9,20$ $\mathrm{mL}$ ) at $80{ }^{\circ} \mathrm{C}$ for $6 \mathrm{~h}$. The solvents were removed in vacuo and the residue was taken up with $\mathrm{CH}_{2} \mathrm{Cl}_{2}$ and was washed with aq. $\mathrm{NaHCO}_{3}$ and brine. Flash chromatography on silica gel (eluent: $\left.\mathrm{CH}_{2} \mathrm{Cl}_{2} / \mathrm{EtOAc}\right)$ afforded 11a $(0.65 \mathrm{~g}, 82 \%, \alpha / \beta=c a .2: 1) .{ }^{1} \mathbf{H} \mathbf{~ N M R}(500 \mathrm{MHz})$ characteristic peaks for $\alpha$-anomer: the reducing end $\mathrm{C} 1 \mathrm{OH}: \delta 2.94(\mathrm{~d}, J=2.5 \mathrm{~Hz}, 1 \mathrm{H})$; six methoxy-H: 3.29 (s, $3 \mathrm{H}), 3.30$ (s, $3 \mathrm{H}), 3.32$ (s, $3 \mathrm{H}$ ), 3.33 (s, $3 \mathrm{H}), 3.37$ (s, $3 \mathrm{H}), 3.38$ (s, 3 $\mathrm{H})$; six $\alpha$-anomeric- $H$ : $5.23(\mathrm{~d}, J=3.0 \mathrm{~Hz}, 1 \mathrm{H}), 5.59(\mathrm{~d}, J=3.5 \mathrm{~Hz}, 1 \mathrm{H}), 5.62(\mathrm{~d}, J=3.5 \mathrm{~Hz}$, $1 \mathrm{H}), 5.67(\mathrm{~m}, 3 \mathrm{H})$; MS (MALDI-TOF) calculated for $\left(\mathrm{C}_{133} \mathrm{H}_{152} \mathrm{O}_{31} \mathrm{Na}^{+}\right): 2268.02$, found: 2268.4; $[\alpha]^{25} \mathrm{D}+57.5\left(\right.$ c $\left.0.40, \mathrm{CHCl}_{3}\right)$.

Spectroscopic data for $\mathbf{1 1 b}(\boldsymbol{\alpha} / \boldsymbol{\beta}=\mathbf{c a} . \mathbf{2} \mathbf{1})-{ }^{\mathbf{1}} \mathbf{H}$ NMR $(500 \mathrm{MHz})$ characteristic peaks for $\alpha$-anomer: the reducing end $\mathrm{C} 1 \mathrm{O} H: \delta 2.94(\mathrm{~d}, J=2.5 \mathrm{~Hz}, 1 \mathrm{H})$; seven methoxy- $H: 3.29$ (s, $3 \mathrm{H}), 3.30$ (s, $3 \mathrm{H}), 3.32$ (s, $3 \mathrm{H}), 3.33$ (s, $3 \mathrm{H}$ ), 3.37 (s, $3 \mathrm{H}), 3.39$ (s, $3 \mathrm{H}), 3.42$ (s, $3 \mathrm{H}$ ); seven $\alpha$-anomeric- $H$ : $5.24(\mathrm{~m}, 1 \mathrm{H}), 5.60(\mathrm{~d}, J=3.5 \mathrm{~Hz}, 1 \mathrm{H}), 5.64(\mathrm{~m}, 5 \mathrm{H})$; MS (MALDITOF) calculated for $\left(\mathrm{C}_{154} \mathrm{H}_{176} \mathrm{O}_{36} \mathrm{Na}^{+}\right)$: 2624.18 , found: $2624.2 ;[\alpha]^{25} \mathrm{D}+79.1$ (c 0.18, $\mathrm{CHCl}_{3}$ ).

Spectroscopic data for $11 \mathbf{c}(\boldsymbol{\alpha} / \boldsymbol{\beta}=\mathbf{c a} . \mathbf{2 : 1})-{ }^{\mathbf{1}} \mathbf{H}$ NMR $(500 \mathrm{MHz})$ characteristic peaks for $\alpha$-anomer: the reducing end $\mathrm{C} 1 \mathrm{O} H: \delta 2.94(\mathrm{~d}, J=2.5 \mathrm{~Hz}, 1 \mathrm{H}$ ); eight methoxy- $H: 3.29$ (s, $3 \mathrm{H}), 3.30$ (s, $3 \mathrm{H}), 3.32$ (s, $3 \mathrm{H}), 3.33$ (s, $3 \mathrm{H}), 3.37$ (s, $3 \mathrm{H}), 3.39$ (s, $3 \mathrm{H}), 3.42$ (s, $3 \mathrm{H}$ ); eight $\alpha$-anomeric- $H$ : 5.23 (t, $J=3.5 \mathrm{~Hz}, 1 \mathrm{H}), 5.60(\mathrm{~d}, J=3.5 \mathrm{~Hz}, 1 \mathrm{H}), 5.63(\mathrm{~d}, J=3.5 \mathrm{~Hz}, 1 \mathrm{H})$, $5.67(\mathrm{~m}, 5 \mathrm{H})$; MS (MALDI-TOF) calculated for $\left(\mathrm{C}_{175} \mathrm{H}_{200} \mathrm{O}_{41} \mathrm{Na}^{+}\right)$: 2980.35, found: 2980.2; $[\alpha]^{25}+79.3\left(c 0.19, \mathrm{CHCl}_{3}\right)$. 
Transformation of 11a c to $12 a \sim c-T h e$ following procedure was applied for all series. To a solution of 11a $(0.50 \mathrm{~g}, 0.22 \mathrm{mmol}), 2$-(2-methoxyethoxy)acetic acid ( $38.4 \mathrm{~mL}, 0.33$ mmol), and DMAP $(13.6 \mathrm{mg}, 0.11 \mathrm{mmol})$ in $\mathrm{CH}_{2} \mathrm{Cl}_{2}(15 \mathrm{~mL})$ at $0{ }^{\circ} \mathrm{C}$ was added $\mathrm{EDCI}(85$ $\mathrm{mg}, 0.446 \mathrm{mmol}$ ) in portions. The cooling bath was removed after $10 \mathrm{~min}$ and the mixture was stirred at RT for $2 \mathrm{~h}$. The mixture was diluted with $\mathrm{CH}_{2} \mathrm{Cl}_{2}(20 \mathrm{~mL})$ and washed with aq. $\mathrm{NaHCO}_{3}$ and brine. Flash chromatography on silica gel (eluent: $\mathrm{CH}_{2} \mathrm{Cl}_{2} / \mathrm{EtOAc}$ ) afforded 12a as a colorless solid $(0.50 \mathrm{~g}, 96 \%, \alpha / \beta=c a .2)$. ${ }^{1} \mathbf{H}$ NMR $(500 \mathrm{MHz})$ characteristic peaks for $\alpha$-anomer: seven methoxy- $H$ : $\delta 3.30$ (s, $3 \mathrm{H}$ ), 3.31 (s, $3 \mathrm{H}$ ), 3.32 (s, $3 \mathrm{H}), 3.34$ (s, $3 \mathrm{H}), 3.38$ (s, $3 \times 2 \mathrm{H}), 3.41(\mathrm{~s}, 3 \mathrm{H})$; six $\alpha$-anomeric- $H$ : $5.61(\mathrm{~d}, J=3.5 \mathrm{~Hz}, 1 \mathrm{H}), 5.63(\mathrm{~d}, J=3.5 \mathrm{~Hz}, 1 \mathrm{H})$, $5.66(\mathrm{~d}, J=3.5 \mathrm{~Hz}, 1 \mathrm{H}), 5.68(\mathrm{~d}, J=3.5 \mathrm{~Hz}, 1 \mathrm{H}), 5.74(\mathrm{~d}, J=3.5 \mathrm{~Hz}, 1 \mathrm{H}), 6.46(\mathrm{~d}, J=3.5$ $\mathrm{Hz}, 1 \mathrm{H}$ ); MS (MALDI-TOF) calculated for $\left(\mathrm{C}_{138} \mathrm{H}_{160} \mathrm{O}_{34} \mathrm{Na}^{+}\right)$: 2384.07, found: 2384.2; $[\alpha]^{25} \mathrm{D}+80.1\left(c 0.23, \mathrm{CHCl}_{3}\right)$.

Spectroscopic data for $\mathbf{1 2 b}(\boldsymbol{\alpha} / \boldsymbol{\beta}=\mathbf{c a} . \mathbf{2}: \mathbf{1})-{ }^{\mathbf{1}} \mathbf{H}$ NMR $(500 \mathrm{MHz})$ characteristic peaks for $\alpha$-anomer: eight methoxy- $H$ : $\delta 3.29(\mathrm{~s}, 3 \mathrm{H}), 3.30(\mathrm{~s}, 3 \mathrm{H}), 3.31(\mathrm{~s}, 3 \mathrm{H}), 3.32(\mathrm{~s}, 3 \mathrm{H}), 3.36$ $(\mathrm{s}, 3 \mathrm{H}), 3.377(\mathrm{~s}, 3 \mathrm{H}), 3.38(\mathrm{~s}, 3 \times 2 \mathrm{H}), 3.41(\mathrm{~s}, 3 \mathrm{H})$; seven $\alpha$-anomeric- $H$ : 5.59 (d, $J=3.5$ $\mathrm{Hz}, 1 \mathrm{H}), 5.63(\mathrm{~m}, 4 \mathrm{H}), 5.74(\mathrm{~d}, J=3.5 \mathrm{~Hz}, 1 \mathrm{H}), 6.45(\mathrm{~d}, J=3.5 \mathrm{~Hz}, 1 \mathrm{H})$; MS (MALDITOF) calculated for $\left(\mathrm{C}_{159} \mathrm{H}_{184} \mathrm{O}_{39} \mathrm{Na}^{+}\right)$: 2740.23 , found: $2740.0 ;[\alpha]^{25} \mathrm{D}+81.2(c 0.26$, $\mathrm{CHCl}_{3}$ ).

Spectroscopic data for $\mathbf{1 2 c}(\boldsymbol{\alpha} / \boldsymbol{\beta}=\mathbf{c a} . \mathbf{2 : 1})-\mathbf{1} \mathbf{H}$ NMR $(500 \mathrm{MHz})$ characteristic peaks for $\alpha$-anomer: nine methoxy- $H$ : $\delta 3.29(\mathrm{~s}, 3 \mathrm{H}), 3.30(\mathrm{~s}, 3 \mathrm{H}), 3.318(\mathrm{~s}, 3 \mathrm{H}), 3.322(\mathrm{~s}, 3 \mathrm{H})$, $3.36(\mathrm{~s}, 3 \mathrm{H}), 3.37(\mathrm{~s}, 3 \mathrm{H}), 3.38(\mathrm{~s}, 3 \times 2 \mathrm{H}), 3.41(\mathrm{~s}, 3 \mathrm{H})$; eight a-anomeric- $H$ : $5.59(\mathrm{~d}, J=$ $3.5 \mathrm{~Hz}, 1 \mathrm{H}), 5.64(\mathrm{~d}, J=3.5 \mathrm{~Hz}, 1 \mathrm{H}), 5.66(\mathrm{~m}, 4 \mathrm{H}), 5.75(\mathrm{~d}, J=3.5 \mathrm{~Hz}, 1 \mathrm{H}), 6.45(\mathrm{~d}, J=$ $3.5 \mathrm{~Hz}, 1 \mathrm{H}$ ); MS (MALDI-TOF) calculated for $\left(\mathrm{C}_{180} \mathrm{H}_{208} \mathrm{O}_{44} \mathrm{Na}^{+}\right)$: 3096.39, found: 3095.8; $[\alpha]^{25} \mathrm{D}+83.2\left(c 0.25, \mathrm{CHCl}_{3}\right)$.

\section{Glycosidations summarized in Scheme 7}

General note on glycosidation reactions-Precautions: For handling of anhydrous $\mathrm{AgClO}_{4}$, see: Perrin, D. D.; Armarego, W. L. F. Purification of Laboratory Chemicals, $3^{\text {rd }}$ ed.; Pergamon, New York, NY, 1988 and Encyclopedia of Reagents for Organic Synthesis, Paquette, L. A. Ed, John Wiley \& Son, New York, NY, 1995. All solvents were freshly distilled prior to use $\left(\mathrm{CH}_{2} \mathrm{Cl}_{2}\right.$ from $\mathrm{CaH}_{2} ; \mathrm{Et}_{2} \mathrm{O}$ from $\left.\mathrm{LiAlH}_{4}\right)$ and transferred via cannula into the solvent flasks. All flasks were flame dried just before use. Syringes, septa, needles, $\mathrm{AgClO}_{4}$ (placed in a pear-shaped flask equipped with a stirrer bar, septum and needle), aluminum foil, stoppers, and plastic bags were dried over $\mathrm{P}_{2} \mathrm{O}_{5} /$ Drierite in a desiccator in vacuo overnight. The starting materials were also dried over $\mathrm{P}_{2} \mathrm{O}_{5}$ under reduced pressure overnight. After all the reagents, solvents, and the desiccator have been placed in a glove bag, the atmosphere is exchanged three times with nitrogen (introduced through Drierite plug).

Glycosidation to form $13 \mathrm{a}-\mathrm{To} \mathrm{AgClO}_{4}(52 \mathrm{mg}, 0.25 \mathrm{mmol})$ in a $10 \mathrm{~mL}$ pear-shaped flask equipped with a stirring bar was added $\mathrm{Et}_{2} \mathrm{O}(5 \mathrm{~mL})$. This suspension was stirred for twenty minutes and the flask was wrapped with aluminum foil to avoid light. To the $\mathrm{AgClO}_{4}$ suspension was added $\mathrm{SnCl}_{4}(30 \mathrm{~mL}, 0.25 \mathrm{mmol})$ was slowly and the mixture was stirred for an additional twenty minutes. The suspension was then left to stand for 5 minutes to allow $\mathrm{AgCl}$-precipitate to settle down. To the reaction flask, which was equipped with a stirring bar and sealed with a septum, was added the supernatant of the Mukaiyama acid solution (0.36 $\mathrm{mL}, 0.018 \mathrm{mmol})$. The starting materials ( $\alpha$-anomer enriched $9 \mathrm{a}(45 \mathrm{mg}, 0.018 \mathrm{mmol})$ and 12a $(44 \mathrm{mg}, 0.018 \mathrm{mmol})$ ) were dissolved in $\mathrm{CH}_{2} \mathrm{Cl}_{2}(0.36 \mathrm{~mL})$ and the solution was transferred into a $1 \mathrm{ml}$ plastic syringe whose needle exit was fixed on the septum of the catalyst solution and they were carefully placed in two plastic bags to isolate them from outer atmosphere. They were cooled down to $-30^{\circ} \mathrm{C}$ in a cryobath. After allowing for thermal equilibration, the starting 
material solution was added slowly over ten minutes and the solution was stirred for $24 \mathrm{~h}$. The reaction mixture was quenched with aq. $\mathrm{NaHCO}_{3}$ and extracted with $\mathrm{CH}_{2} \mathrm{Cl}_{2}(2 \mathrm{ml})$, dried over $\mathrm{Na}_{2} \mathrm{SO}_{4}$ and reduced in vacuo. The crude mixture was stirred in $1 \mathrm{~N} \mathrm{HCl} /$ acetone $(10 \mathrm{ml}, 1: 9)$ for $1 \mathrm{~h}$ at RT to desilylate the unreacted $9 \mathrm{a}(20 \mathrm{mg}, 43 \%$ recovered $)$. The product $(\alpha / \beta$ selectivity of glycosidation $=c a$. 5.5:1 by ${ }^{1} \mathrm{H}$ NMR spectrum) was purified by of two successive flash chromatography on silica gel. The first chromatography (hexanes/THF) was used to remove the by-product and the second chromatography $\left(\mathrm{CH}_{2} \mathrm{Cl}_{2} / \mathrm{EtOAc}\right)$ was used to isolate the desired $\alpha$-glycosidation product (isolated $\alpha$-isomer: $43 \mathrm{mg} ; 48 \%$. ${ }^{1} \mathbf{H}$ NMR $(500 \mathrm{MHz})$ characteristic peaks for the product with $\alpha$-allyl terminal: twelve methoxy- $H$ : $\delta 3.284(\mathrm{~s}, 3 \mathrm{H}), 3.297$ (s, 3 H), $3.300(\mathrm{~s}, 3 \mathrm{H}), 3.311(\mathrm{~s}, 3 \mathrm{H}), 3.318(\mathrm{~s}, 3 \mathrm{H}), 3.328(\mathrm{~s}, 3 \mathrm{H}), 3.346(\mathrm{~s}, 3 \times 2 \mathrm{H}), 3.358(\mathrm{~s}, 3$ $\mathrm{H}), 3.402(\mathrm{~s}, 3 \mathrm{H}), 3.477(\mathrm{~s}, 3 \mathrm{H}), 3.64(\mathrm{~s}, 3 \mathrm{H})$; MS (MALDI-TOF) calculated for $\left(\mathrm{C}_{262} \mathrm{H}_{276} \mathrm{O}_{73} \mathrm{Na}^{+}\right): 4612.78$, found: $4612.3 ;[\alpha]^{25} \mathrm{D}+72.9\left(c 0.48, \mathrm{CHCl}_{3}\right)$.

Glycosidation to form 13b-With $9 \mathrm{~b}$ ( $\alpha$-anomer enriched, $52 \mathrm{mg}, 0.0184 \mathrm{mmol}), \mathbf{1 2 b}$ (50 $\mathrm{mg}, 0.0184 \mathrm{mmol})$, and the Mukaiyama acid $(0.0184 \mathrm{mmol})$, the glycosidation was conducted under the essentially same conditions: $\alpha / \beta$ selectivity $=c a .5: 1 ; \alpha$-isomer isolated: $48 \mathrm{mg}$, $50 \% .{ }^{1} \mathbf{H}$ NMR $(500 \mathrm{MHz})$ characteristic peaks for the product with $\alpha$-allyl terminal: fourteen methoxy-H: $\delta 3.289$ (s, $3 \mathrm{H}), 3.301$ (s, $3 \mathrm{H}), 3.306(\mathrm{~s}, 3 \times 2 \mathrm{H}), 3.316(\mathrm{~s}, 3 \mathrm{H}), 3.321(\mathrm{~s}, 3 \mathrm{H})$, 3.327(s, $3 \mathrm{H}$ ), 3.358 (s, $3 \times 3 \mathrm{H}$ ), 3.364 (s, $3 \mathrm{H}), 3.408$ (s, $3 \mathrm{H}$ ), 3.483 (s, $3 \mathrm{H}), 3.647$ (s, $3 \mathrm{H}$ ); MS (MALDI-TOF) calculated for $\left(\mathrm{C}_{304} \mathrm{H}_{320} \mathrm{O}_{85} \mathrm{Na}^{+}\right)$: 5353.06, found: $5353.1 ;[\alpha]^{25} \mathrm{D}+76.3$ (c $0.66, \mathrm{CHCl}_{3}$ ).

Glycosidation to form 13c-With 9c ( $\alpha$-anomer enriched, $32 \mathrm{mg}, 0.010 \mathrm{mmol}$ ), $12 \mathrm{c}$ (31 $\mathrm{mg}, 0.010 \mathrm{mmol})$, and the Mukaiyama acid $(0.010 \mathrm{mmol})$, the glycosidation was conducted under the essentially same conditions: $\alpha / \beta$ selectivity $=c a .5: 1 ; \alpha$-isomer isolated: $28 \mathrm{mg}$, 46\%. ${ }^{1} \mathbf{H}$ NMR $(500 \mathrm{MHz})$ characteristic peaks for the product with $\alpha$-allyl terminal: sixteen methoxy- $H$ : $\delta 3.288(\mathrm{~s}, 3 \mathrm{H}), 3.300-3.325(7 \mathrm{~s}, 3 \times 7 \mathrm{H}), 3.360(\mathrm{~s}, 3 \times 5 \mathrm{H}), 3.407(\mathrm{~s}, 3 \mathrm{H}), 3.481$ $(\mathrm{s}, 3 \mathrm{H}), 3.646(\mathrm{~s}, 3 \mathrm{H})$; MS (MALDI-TOF) calculated for $\left(\mathrm{C}_{346} \mathrm{H}_{364} \mathrm{O}_{97} \mathrm{Na}^{+}\right): 6093.34$, found: 6093.6; $[\alpha]^{25}+83.0\left(c 0.32, \mathrm{CHCl}_{3}\right)$.

Glycosidations with $\beta$-anomer enriched acceptors $9 \mathbf{a} \sim \mathbf{c}$ were also carried out under the essentially same conditions. For details, see Supporting Information.

\section{Deprotection summarized in Scheme 7}

$\mathbf{\alpha}-\mathbf{1 4 a}$-To a solution of 13a ( $\alpha$-allyl anomer, $20 \mathrm{mg}$, $4.3 \mathrm{mmol}$ ) in THF-MeOH (3 mL. 2:1) was added $10 \% \mathrm{Pd}(\mathrm{OH})_{2}$ on carbon $(10 \mathrm{mg})$. The mixture was equipped with a $\mathrm{H}_{2}$ balloon and was stirred for $24 \mathrm{~h}$. The reaction mixture was passed through a sintered-glass filter with thorough rinsing with $\mathrm{CH}_{2} \mathrm{Cl}_{2}-\mathrm{MeOH}(30 \mathrm{~mL}, 2: 1)$. The filtrate was concentrated with an evaporator and the residue was taken up with $\mathrm{CH}_{2} \mathrm{Cl}_{2}(2.0 \mathrm{~mL})$. To the mixture was added 0.1 $\mathrm{M} \mathrm{NaOMe}$ in $\mathrm{MeOH}(1.0 \mathrm{~mL}, 0.1 \mathrm{mmol})$. The mixture was stirred at $\mathrm{RT}$ for $12 \mathrm{~h}$ and neutralized by adding $1 \mathrm{~N} \mathrm{HCl}(0.1 \mathrm{~mL}, 0.1 \mathrm{mmol})$. After evaporation of solvents, the residue was subjected to reverse phase $\mathrm{C}_{18}$-column chromatography (eluent: $\mathrm{H}_{2} \mathrm{O} / \mathrm{MeOH}: 3 / 1$ to $1 / 1$ ) to furnish $s$ MGP 12-mer 14a $(8.1 \mathrm{mg}, 86 \%)$. The product was further purified by HPLC on a reverse phase $\mathrm{C}_{18}$-column with an RI detector (eluent: $\left.\mathrm{MeOH} / \mathrm{H}_{2} \mathrm{O}\right) .{ }^{1} \mathbf{H} \mathbf{N M R}\left(\mathrm{D}_{2} \mathrm{O}, 500 \mathrm{MHz}\right): \delta 0.90$ (t, $J=7.5 \mathrm{~Hz}, 3 \mathrm{H}), 1.61(\mathrm{~m}, 2 \mathrm{H}), 3.38(\mathrm{~s}, 3 \times 11 \mathrm{H}), 3.39(\mathrm{~s}, 3 \mathrm{H}), 3.43(\mathrm{t}, J=9.5 \mathrm{~Hz}, 1 \mathrm{H})$, 3.44-3.95 (m, $73 \mathrm{H}), 4.88(\mathrm{~d}, J=4.0 \mathrm{~Hz}, 1 \mathrm{H}), 5.37(\mathrm{~d}, J=4.0 \mathrm{~Hz}, 1 \mathrm{H}), 5.42(\mathrm{~m}, 10 \mathrm{H}) ; \mathbf{M S}$ (MALDI-TOF) calculated for $\left(\mathrm{C}_{87} \mathrm{H}_{152} \mathrm{O}_{61} \mathrm{Na}^{+}\right): 2195.87$, found: $2196.0 ;[\alpha]^{25}{ }_{\mathrm{D}}+213(c$ $\left.0.28, \mathrm{H}_{2} \mathrm{O}\right)$.

$\mathbf{\alpha}-\mathbf{1 4 b} \mathbf{b}$-The deprotection was performed under the same conditions, where $\mathbf{1 3 b}$ ( $\alpha$-anomer enriched, $20 \mathrm{mg}, 7.5 \mathrm{mmol})$ gave 14b $(10.2 \mathrm{mg}(68 \%)) .{ }^{\mathbf{1}} \mathbf{H} \mathbf{N M R}\left(\mathrm{D}_{2} \mathrm{O}, 500 \mathrm{MHz}\right): \delta 0.89$ (t, $J=7.5 \mathrm{~Hz}, 3 \mathrm{H}), 1.60(\mathrm{~m}, 2 \mathrm{H}), 3.37(\mathrm{~s}, 3 \times 13 \mathrm{H}), 3.38(\mathrm{~s}, 3 \mathrm{H}), 3.42(\mathrm{t}, J=9.5 \mathrm{~Hz}, 1 \mathrm{H})$, 
3.54-3.94 (m, $85 \mathrm{H}), 4.89(\mathrm{~d}, J=4.0 \mathrm{~Hz}, 1 \mathrm{H}), 5.36(\mathrm{~d}, J=4.0 \mathrm{~Hz}, 1 \mathrm{H}), 5.42(\mathrm{~m}, 12 \mathrm{H}) ; \mathbf{M S}$ (MALDI-TOF) calculated for $\left(\mathrm{C}_{101} \mathrm{H}_{176} \mathrm{O}_{71} \mathrm{Na}^{+}\right)$: 2548.01, found: $2548.2 ;[\alpha]^{25}{ }_{\mathrm{D}}+203(c$ $\left.0.29, \mathrm{H}_{2} \mathrm{O}\right)$.

$\boldsymbol{\alpha}-\mathbf{1 4 c}-$ The deprotection was performed under the same conditions, where $13 \mathbf{c}$ ( $\alpha$-anomer enriched, $62 \mathrm{mg}, 10 \mathrm{mmol})$ gave $\mathbf{1 4 c}(19.5 \mathrm{mg}(68 \%)) .{ }^{\mathbf{1}} \mathbf{H} \mathbf{N M R}\left(\mathrm{D}_{2} \mathrm{O}, 500 \mathrm{MHz}\right): \delta 0.89(\mathrm{t}$, $J=7.5 \mathrm{~Hz}, 3 \mathrm{H}), 1.61(\mathrm{~m}, 2 \mathrm{H}), 3.37(\mathrm{~s}, 3 \times 15 \mathrm{H}), 3.38(\mathrm{~s}, 3 \mathrm{H}), 3.43(\mathrm{t}, J=9.5 \mathrm{~Hz}, 1 \mathrm{H})$, 3.54-3.94 (m, $97 \mathrm{H}), 4.89(\mathrm{~d}, J=4.0 \mathrm{~Hz}, 1 \mathrm{H}), 5.36(\mathrm{~d}, J=4.0 \mathrm{~Hz}, 1 \mathrm{H}), 5.42(\mathrm{~m}, 14 \mathrm{H})$; MS (MALDI-TOF) calculated for $\left(\mathrm{C}_{115} \mathrm{H}_{200} \mathrm{O}_{81} \mathrm{Na}^{+}\right): 2900.14$, found: $2900.0 ;[\alpha]^{25}{ }_{\mathrm{D}}+205(c$ $\left.0.28, \mathrm{H}_{2} \mathrm{O}\right)$.

Using the same protection procedure, $\beta$-enriched $s$ MGPs 12-, 14-, and 16-mers were prepared. For details, see Supporting Information.

For details for the synthesis summarized in Schemes 8 and 9, see Supporting Information.

\section{Supplementary Material}

Refer to Web version on PubMed Central for supplementary material.

\section{Acknowledgements}

Financial support from the National Institutes of Health (NS 12108) and Eisai Research Institute is gratefully acknowledged.

\section{References}

1. Hsu, M. C.-P.; Lee, J.; Kishi, Y. preceding paper.

2. For isolation and structural characterization of MMP, see: (a) Gray GR, Ballou CE. J Biol Chem 1971;246:6835. [PubMed: 5166559] (b) Maitra SK, Ballou CE. J Biol Chem 1977;252:2459. [PubMed: 856790] (c) Weisman LS, Ballou CE. J Biol Chem 1984;259:3457. [PubMed: 6706966] (d) Weisman LS, Ballou CE. J Biol Chem 1984;259:3464. [PubMed: 6706967] (e) Ilton M, Jevans AW, McCarthy ED, Vance D, White HB III, Bloch K. Proc Natl Acad Sci USA 1971;68:87. [PubMed: 5276305]

3. For isolation and structural characterization of MGLP, see: (a) Lee YC, Ballou CE. J Biol Chem 1964;239:PC3602. [PubMed: 14245425] (b) Saier MH Jr, Ballou CE. J Biol Chem 1968;243:4332. [PubMed: 5679967] (c) Smith WL, Ballou CE. J Biol Chem 1973;248:7118. [PubMed: 4743516] (d) Forsberg LS, Dell A, Walton DJ, Ballou CE. J Biol Chem 1982;257:3555. [PubMed: 7061496] Regarding the structural heterogeneity of MGP, Ballou commented that at least two forms of MGP containing 21 hexoses exist: Kamisango K, Dell A, Ballou CE. J Biol Chem 1987;262:4580. [PubMed: 3558356]Also see, Tuffal G, Albigot R, Monsarrat B, Ponthus C, Picard C, Rivière M, Puzo G. J Carbohydr Chem 1995;14:631.

4. The structure of MG(L)P shown in Figure 1 is the revised structure suggested by Rivière based on the structure of polysaccharide isolated from Mycobacterium bovis BCG. See: Tuffal G, Albigot R, Rivière M, Puzo G. Glycobiology 1998;8:675. [PubMed: 9621108]

5. For reviews on MMP and MGLP/MGP, see: (a) Bloch K. Advances in Enzymology 1977;45:1. (b) Ballou CE. Accts Chem Res 1968;1:366. (c) Ballou CE. Pure \& Appl Chem 1981;53:107.

6. For examples, see the reviews cited in references 9 and 10 in the preceding paper.

7. For examples, see the syntheses cited in reference 11 in the preceding paper.

8. Koto S, Haigoh H, Shichi S, Hirooka M, Nakamura T, Maru C, Fijita M, Goto A, Sato T, Okada M, Zen S, Yago K, Tomonaga F. Bull Chem Soc Jpn 1995;68:2331.

9. (a) Mukaiyama T, Takashima T, Katsurada M, Aizawa H. Chem Lett 1991:533. (b) Mukaiyama T, Katsurada M, Takashima T. Chem Lett 1991:985. (c) Mukaiyama T, Matsubara K, Sasaki T, Mukaiyama T. Chem Lett 1993:1373. 
10. Wang, Y.; Cheon, H.-S.; Lee, J.; Kishi, Y. a manuscript in preparation.

11. (a) Fugedi P. Carbohydr Res 1989;192:366. (b) Pregel MJ, Buncel E. Can J Chem 1991;69:130. (c) Takeo K, Uemura K, Mitoh M. J Carbohydr Chem 1998;7:293.

12. $4 \mathrm{a}$ was previously prepared by methylation $\left(\mathrm{BF}_{3} / \mathrm{CH}_{2} \mathrm{~N}_{2}\right)$ of $3 \mathrm{a}$ : see ref. $11 \mathrm{a}$.

13. 3a was previously prepared by controlled hydrolysis ( $\left.{ }^{\mathrm{i}} \mathrm{PrOK} / \mathrm{PrOH}-\mathrm{benzene}\right)$ of perbenzoylated $\alpha$ CD: see (a) Boger J, Corcoran RJ, Lehn JM. Helv Chim Acta 1978;61:2190. (b) Uccello-Barretta G, Cuzzola A, Balzana F, Menicagli R, Iuliano A, Salvadori P. J Org Chem 1997;62:827.

14. For cleavage of peracylated cyclodextrins, see: (a) Sakari N, Wang L-X, Kuzuhara H. J Chem Soc, Chem Commun 1991:289. (b) Sakari N, Wang L-X, Kuzuhara H. J Chem Soc, Perkin Trans 1 1995:437. (c) Sakari N, Matsui K, Kuzuhara H. Carbohydr Res 1995;266:263. [PubMed: 7697657] (d) Sakairi N, Kuzuhara H. Carbohydr Res 1996;280:139. [PubMed: 8581893]

15. Green, TW.; Wuts, PG. Protective Groups in Organic Synthesis. 3. John Wiley \& Sons; New York: 1999. p. 160-166.and references cited therein

16. The products were isolated as a mixture of $\alpha / \beta$-anomers at the reducing ends with ca. 10:1 ratios favoring $\alpha$-anomers. The homogeneity of products was assessed by ${ }^{1}$ H NMR and MS (MALDI-TOF), and was further confirmed by transforming them to the known acceptors $9 \mathrm{a} \sim \mathrm{c}$.

17. Following the same sequences as shown in Schemes 6 and 7, $\beta$-anomer enriched $9 a \sim c$ were converted to the $\beta$-anomer enriched $s$ MGP 14a c. For details, see Supporting Information.

18. The profile of Mukaiyama glycosidation in the glucose series was different from that in the mannose series. However, considering the total number of glycosidic bonds present in the product as well as the starting materials, we were concerned with the possibility that the "truncated/scrambled" products might be contaminated in the products in the gluco series as well. To address this issue, the glycosidation was purposely run for a prolonged time at $0{ }^{\circ} \mathrm{C}$, and the product was subjected to the mass spectrometry and size-exclusion chromatography, thereby showing that the product mixture thus obtained was indeed contaminated by a small amount of "truncated" oligomers. Interestingly, these oligomers were formed by cleavage of glycosidic bonds exclusively at the hexoses bearing benzyl protection groups, suggesting that electron-withdrawing groups on $\mathrm{C} 2$ hydroxyl groups destabilize carbocation-formation and suppress the truncation. When the reaction was carried out at $-30{ }^{\circ} \mathrm{C}$, the process forming the "truncated" oligomers was completely suppressed.

19. Based on the ${ }^{1} \mathrm{H}$ NMR analysis, the major by-product appeared to be a benzyl glycoside of the donors.

20. An extensive study on the ${ }^{1}$ H NMR spectrum was carried out; the absence of the doublet peak $(J=$ $8.0 \mathrm{~Hz})$ at $4.48 \mathrm{ppm}$ demonstrated no contamination with the $\beta$-anomer at the newly introduced anomeric center. Similarly, the absence of the doublet $(J=8.0 \mathrm{~Hz})$ at $4.45 \mathrm{ppm}$ demonstrated no contamination with the $\beta$-propyl anomer at the reducing end.

21. For details, see Supporting Information.

22. Structure assignment in the $s$ EMG 14-mer series was made, based on the ${ }^{1} \mathrm{H}$ NMR analysis in comparison with the corresponding $s$ MGP 14-mer series

23. With use of the reported synthetic route, sMGP 6-, 7-, 8-, 10-, 12-, 14-, 16-, 18-, and 20-mers were synthesized. For details, see Supporting Information.

24. Cheon HS, Wang Y, Ma J, Kishi Y. ChemBioChem. in press (b) Papaioannou, N.; Cheon, H.-S.; Kishi, Y. a manuscript in preparation.

25. Cheon, H.-S.; Kishi, Y. a manuscript in preparation. 


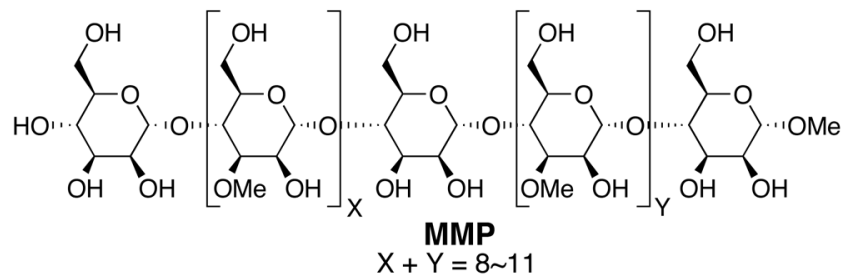

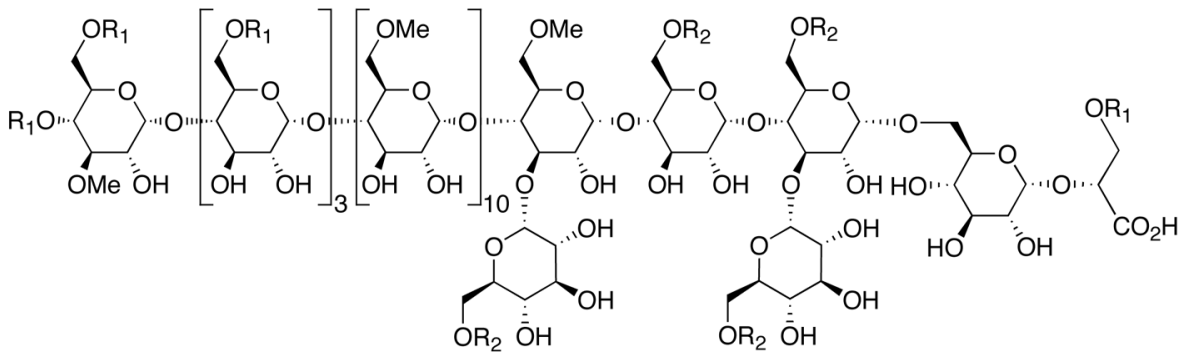

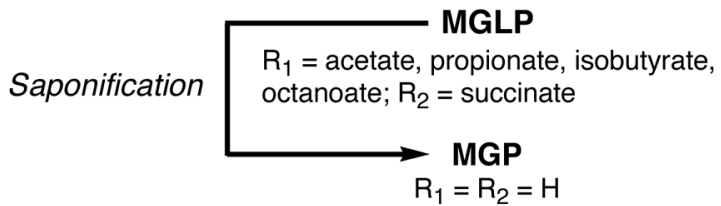

Figure 1.

Structures of mycobacterial polysaccharides 3-O-methyl-D-mannose-containing polysaccharides (MMP) and 6-O-methyl-D-glucose-containing lipopolysacchrides (MGLP)/ 6-O-methyl-D-glucose-containing polysaccharide (MGP). 


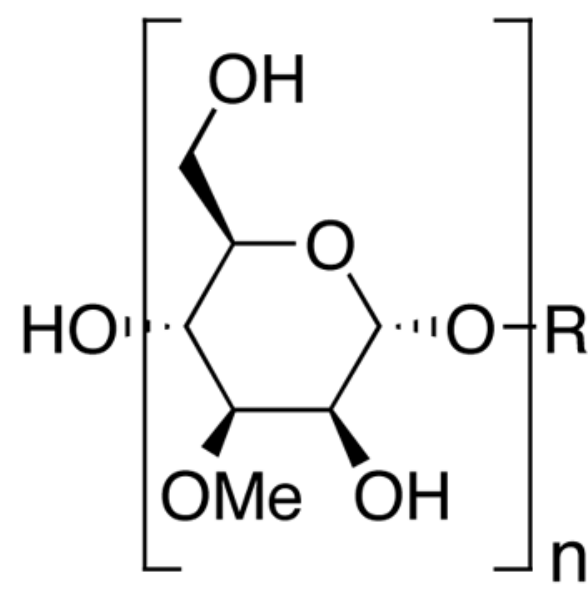

sMMP

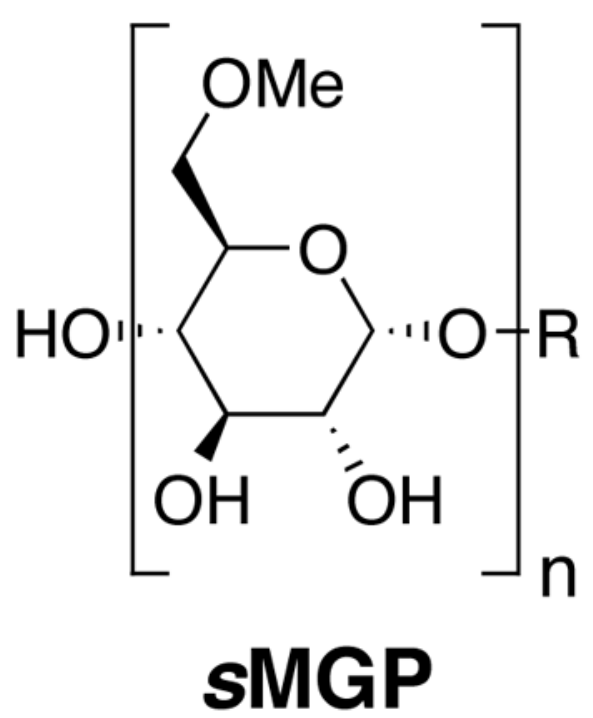

Figure 2.

Structures of synthetic analogs of mycobacterial polysaccharides, $s$ MMP and $s$ MGP. 

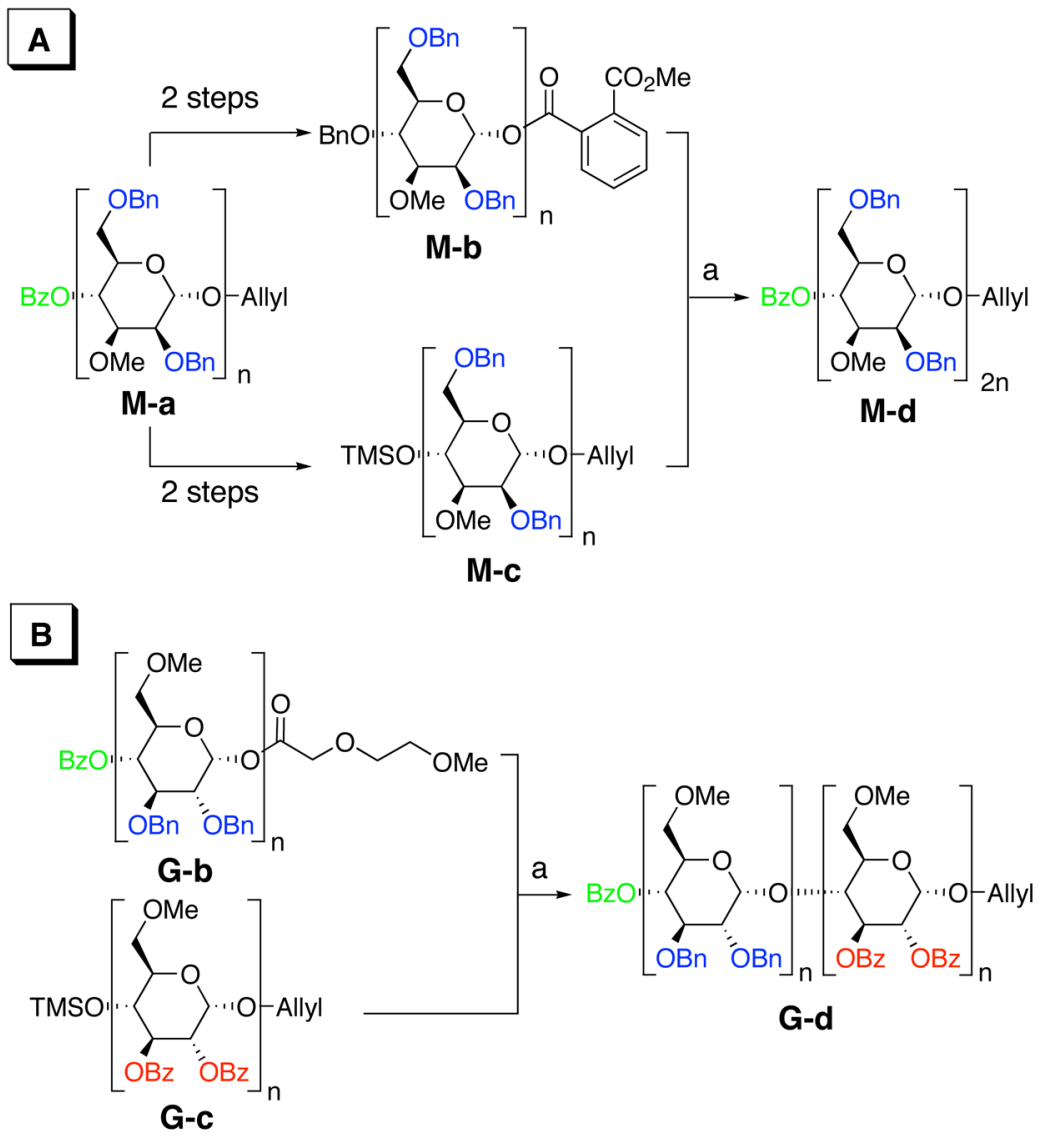

Scheme 1.

Divergent synthetic strategies of $s$ MMP (Panel A) and $s$ MGP (Panel B). (a) Mukaiyama glycosidation: $10 \mathrm{~mol} \% \mathrm{AgClO}_{4}-\mathrm{SnCl}_{4}, \mathrm{Et}_{2} \mathrm{O}, 0{ }^{\circ} \mathrm{C}$. 


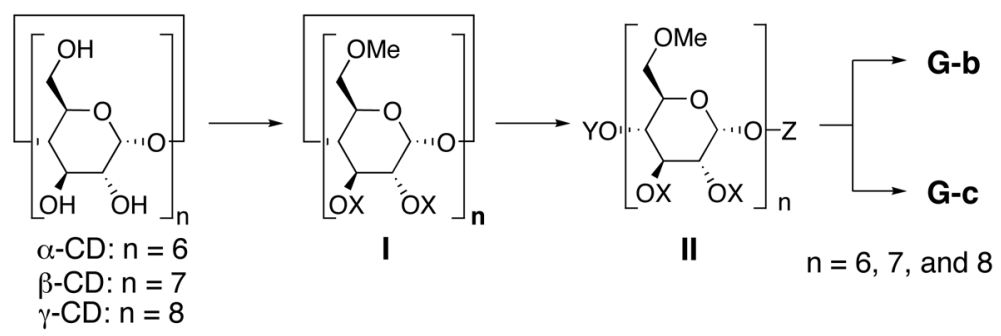

Scheme 2.

Synthetic plan for the glycosyl donor G-b and the glycosyl acceptor G-c from $\alpha-, \beta-$, and $\gamma$ CDs. 


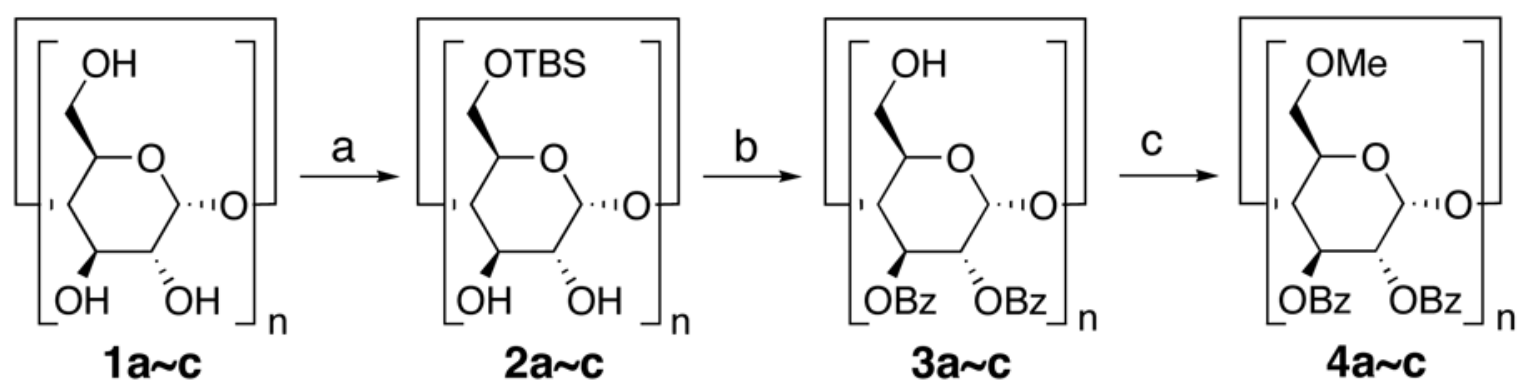

a: $\alpha$-CD series, $n=6 ; \mathbf{b}: \beta-C D$ series, $n=7 ; \mathbf{c}: \gamma$-CD series, $n=8$

Scheme 3.

Reagents and conditions: (a) TBSCl, pyr, rt (a: 83\%; b: 83\%; c: 78\%); (b) 1. BzOTf, pyr, rt (a: $95 \%$ ) or $\mathrm{BzCl}$, pyr, $50{ }^{\circ} \mathrm{C}$ (b: $93 \%$; c: $90 \%$ ); 2. aq. $\mathrm{HF}, \mathrm{CH}_{2} \mathrm{Cl}_{2}-\mathrm{CH}_{3} \mathrm{CN}$, rt (a: $83 \%$; b:

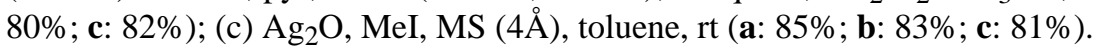




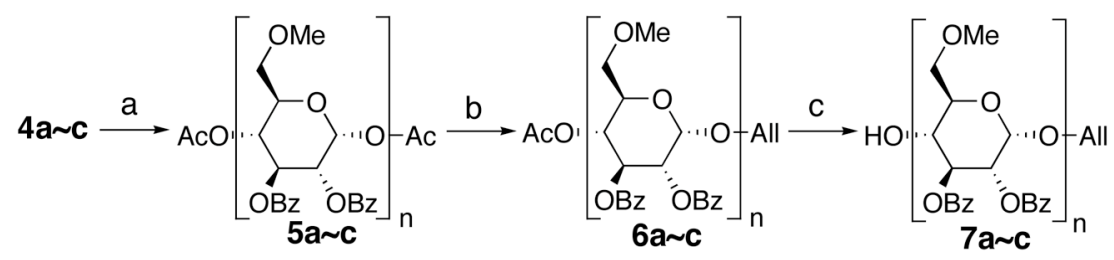

a: $\alpha$-CD series, $n=6 ; \mathbf{b}$ : $\beta$-CD series, $n=7 ; \mathbf{c}: \gamma-C D$ series, $n=8$

Scheme 4.

Reagents and conditions: (a) $2 \% \mathrm{H}_{2} \mathrm{SO}_{4}$ in $\mathrm{Ac}_{2} \mathrm{O}$, rt (a: $71 \%$; b: $66 \%$; c: $55 \%$ ); (b) 1 .

$\mathrm{BnNH}_{2}$, THF, rt (a: 96\%; b: 93\%; c: 92\%); 2. $\mathrm{Ag}_{2} \mathrm{O}, \mathrm{MS}(4 \AA$ A ), allyl bromide, DMF, rt (a: 90\%; b: $97 \%$; c: $93 \%$ ); (c) $\mathrm{HBF}_{4}, \mathrm{CH}_{2} \mathrm{Cl}_{2}-\mathrm{MeOH}(3: 1), 40{ }^{\circ} \mathrm{C}(\mathbf{a}: 54 \%$, b: $44 \%$; c: $52 \%)$. 


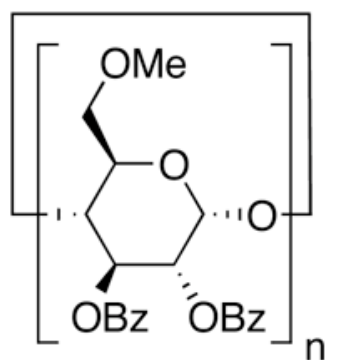

4a c

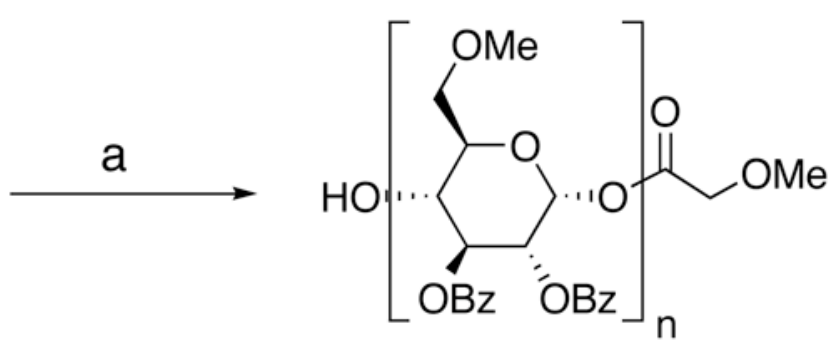

$8 a \sim c$

a: $\alpha$-CD series, $n=6 ; \mathbf{b}: \beta-C D$ series, $n=7 ; \mathbf{c}: \gamma$-CD series, $n=8$

Scheme 5.

Reagents and conditions: (a) $\alpha$-CD 4a: $\mathrm{BF}_{3} \cdot \mathrm{Et}_{2} \mathrm{O}(12 \% \mathrm{v} / \mathrm{v}), \mathrm{MeOCH}_{2} \mathrm{CO}_{2} \mathrm{H}-\mathrm{CH}_{2} \mathrm{Cl}_{2}(12 \% \mathrm{v} /$ $\mathrm{v} ;[C]=0.01 \mathrm{M}), 40^{\circ} \mathrm{C}, 1 \mathrm{~h}, 82 \%$ yield (recrystallization). $\beta$-CD $4 \mathbf{b}$ and $\gamma$-CD $4 \mathbf{c}$ : see Table 3. 


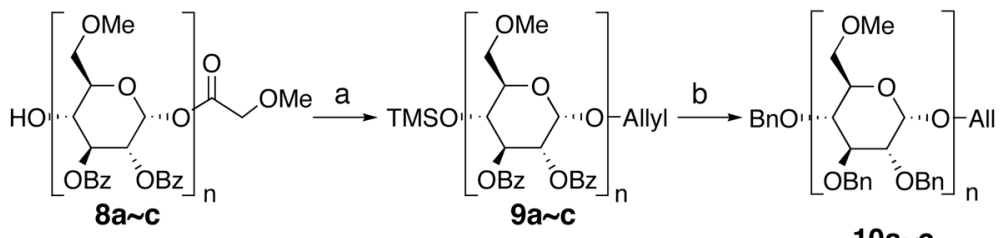

8a c

9a c

$10 a \sim c$

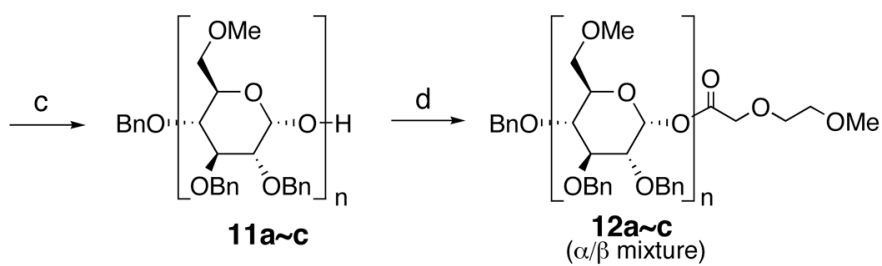

a: $\alpha$-CD series, $n=6$; $\mathbf{b}$ : $\beta$-CD series, $n=7 ; \mathbf{c}: \gamma-C D$ series, $n=8$

\section{Scheme 6.}

Reagents and conditions: (a) 1. TMSOTf, $\mathrm{Et}_{3} \mathrm{~N}, \mathrm{CH}_{2} \mathrm{Cl}_{2}$ (a: 96\%; b: 93\%; c: 95\%); 2. ethanolamine, $\mathrm{CH}_{2} \mathrm{Cl}_{2}$ (a: $92 \%$; b: $86 \%$; c: $86 \%$ ); 3. Allyl bromide, $\mathrm{Ag}_{2} \mathrm{O}, \mathrm{MS}(4 \AA)$, DMF, rt (a: $92 \%$; b: $86 \%$; c: $91 \%$ ); (b) (i) $\mathrm{H}_{3} \mathrm{O}^{+}$; (ii) $\mathrm{NaOMe}, \mathrm{MeOH}_{-} \mathrm{CH}_{2} \mathrm{Cl}_{2}$ (1:1), rt; (iii) $\mathrm{NaH}, \mathrm{BnBr}$, DMF, rt (a: 77\%; b: 87\%; c: 71\%). (c) 1. $\left(\mathrm{Ph}_{3} \mathrm{P}\right)_{3} \mathrm{RhCl}$, Dabco, EtOH-toluene- $\mathrm{H}_{2} \mathrm{O}$ (6:3:1), 90 ${ }^{\circ} \mathrm{C}$; 2. acetone-1N HCl $(9: 1), 90{ }^{\circ} \mathrm{C}(\mathbf{a}: 82 \%$; b: 76\%; c: 77\%); (d) EDCI, DMAP, 2-(2methoxyethoxy)acetic acid, $\mathrm{CH}_{2} \mathrm{Cl}_{2}, 0{ }^{\circ} \mathrm{C}$ (a: $96 \%$; b: $96 \%$; c: $91 \%$ ). 


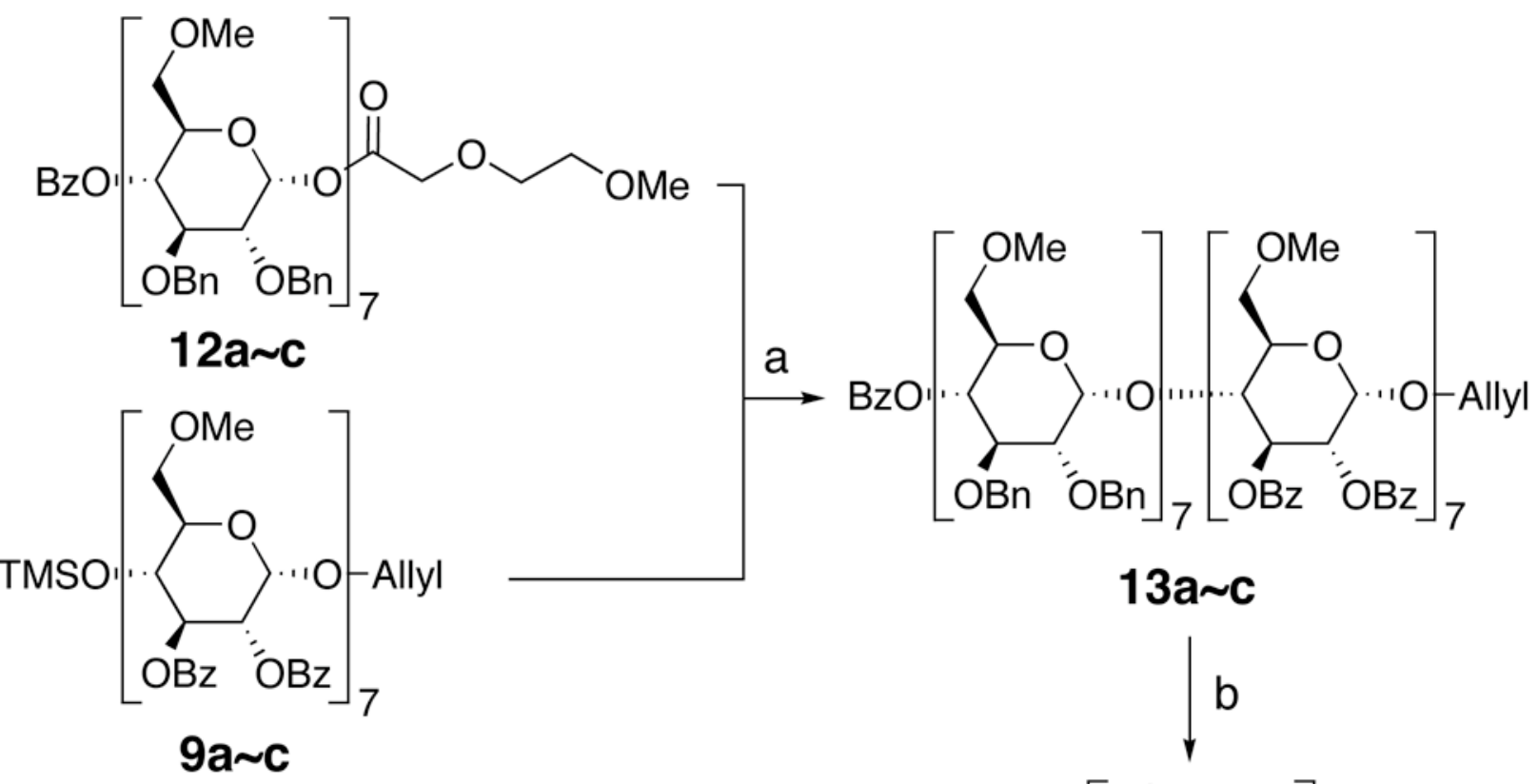

a: $\alpha-C D$ series, $n=6$

b: $\beta$-CD series, $n=7$

c: $\gamma$-CD series, $n=8$

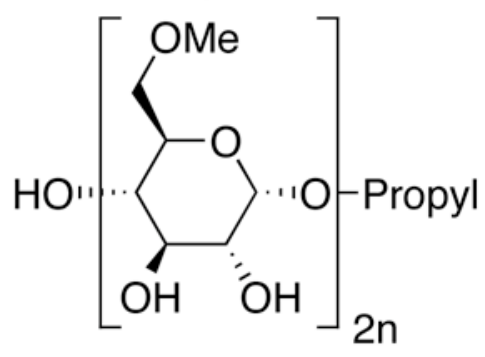

14a c

Scheme 7.

Reagents and conditions: (a) $1.100 \mathrm{~mol} \%$ [ $\left.\mathrm{SnCl}_{3} \mathrm{ClO}_{4}\right], \mathrm{CH}_{2} \mathrm{Cl}_{2}-\mathrm{Et}_{2} \mathrm{O}(2: 1),-30{ }^{\circ} \mathrm{C}$ (a: $49 \%$; b: $50 \%$; c: $51 \%$ ); (b) (i) $\mathrm{H}_{2}, \mathrm{Pd}(\mathrm{OH})_{2}$ on C, THF, rt; (ii) $\mathrm{NaOMe}, \mathrm{CH}_{2} \mathrm{Cl}_{2}-\mathrm{MeOH}(3: 1)$, rt (a: $86 \%$, b: $66 \%$; c: $68 \%$ ). 


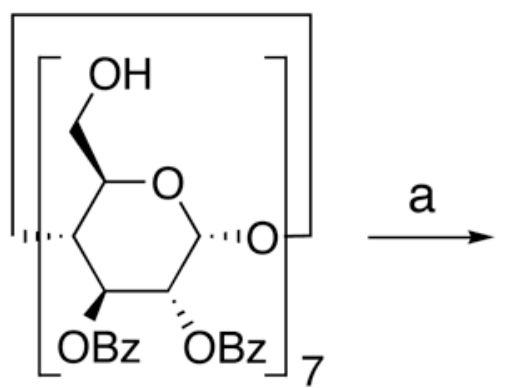

$3 b$

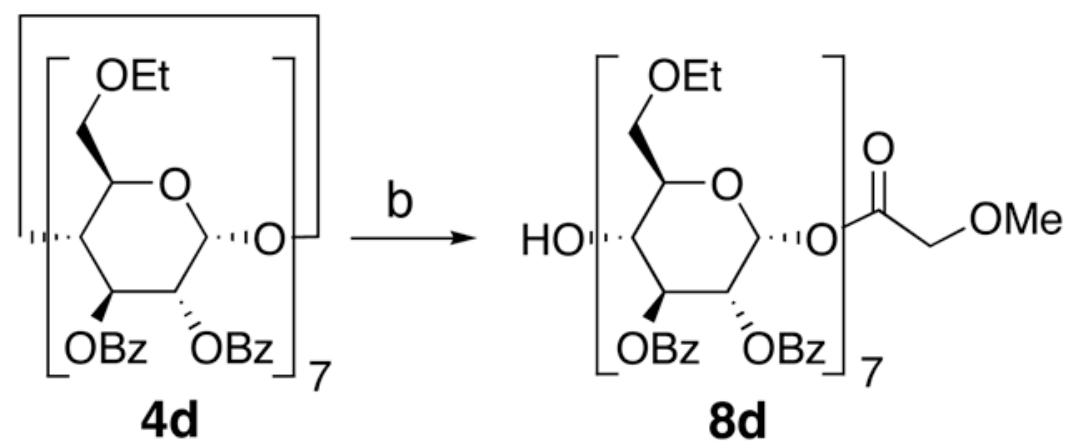

$c$<smiles>[Z4][14CH2][C@H]1O[C@H](COCC)[C@@H](O)[C@H](O)[C@H]1O</smiles>

14d

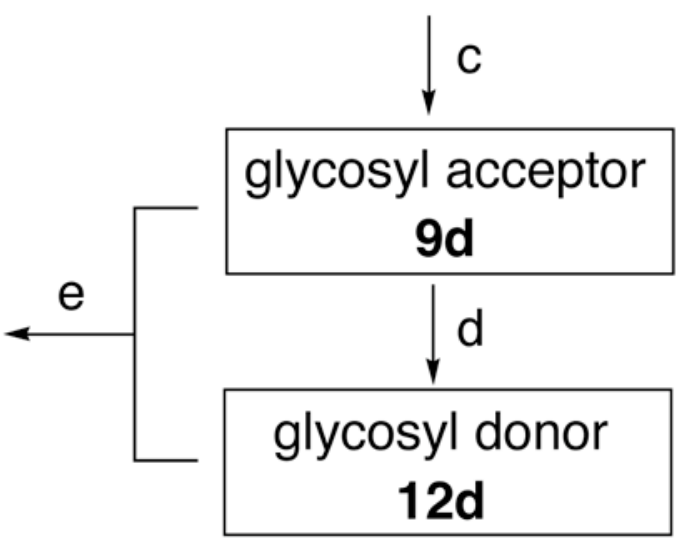

Scheme 8.

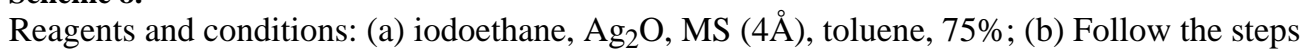
in Table 3; (c) Follow the step a in Scheme 6 (77\% overall yield); (d) Follow the steps b, c and $\mathrm{d}$ in Scheme 6 (69\% overall yield); (e) (1). $200 \mathrm{~mol} \%$ [ $\left.\mathrm{SnCl}_{3} \mathrm{ClO}_{4}\right], \mathrm{CH}_{2} \mathrm{Cl}_{2}-\mathrm{Et}_{2} \mathrm{O}$ (2:1), -30 ${ }^{\circ} \mathrm{C}, 50 \%$; (2) Follow the step b in Scheme 7 (54\% overall yield). For the details, see Supporting Information. 


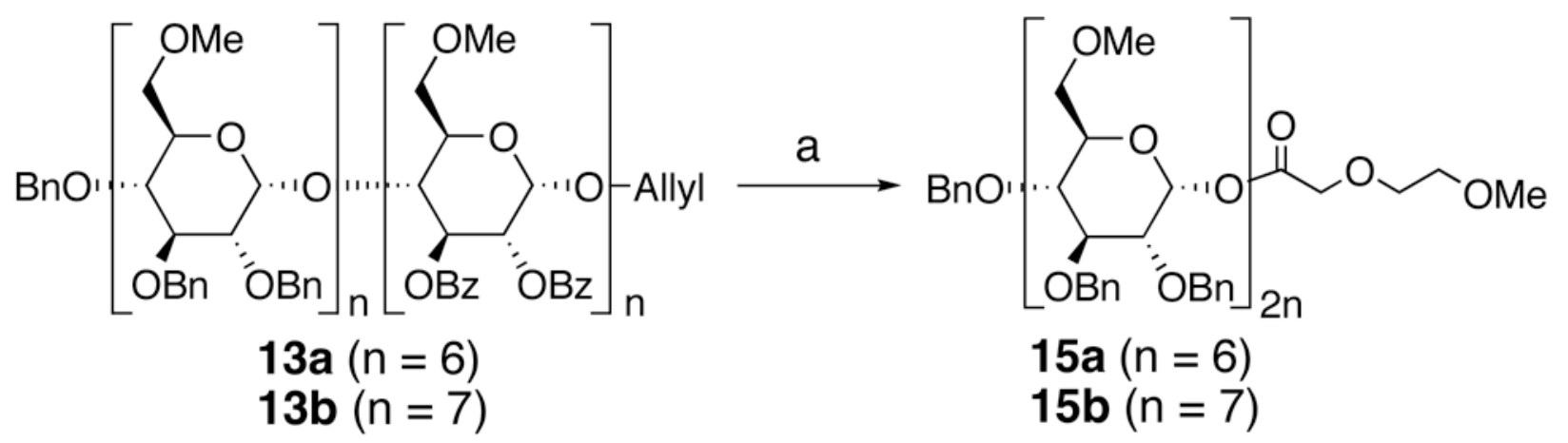<smiles>CO[C@H]1O[C@H](O)[C@@H](O)[C@H](O)[C@H]1O</smiles>

14e sMGP 18-mer $(m=18)$ $14 f$ sMGP 20-mer $(m=20)$

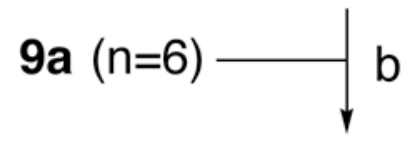

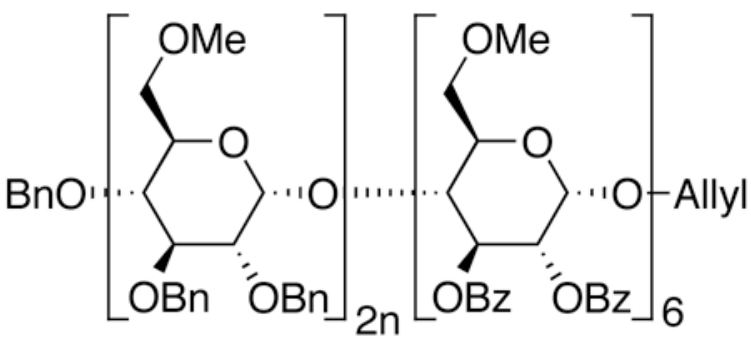

$16 a(n=6)$ $16 b(n=7)$

Scheme 9.

Reagents and conditions: (a) 1. (i) $\mathrm{NaOMe}, \mathrm{MeOH}-\mathrm{CH}_{2} \mathrm{Cl}_{2}$ (1:1), rt.; (ii) $\mathrm{NaH}, \mathrm{BnBr}, \mathrm{DMF}$, rt. (a: 70\%, b: 72\%); 2. (i) Follow the steps c and d in Scheme 6 (a: 57\%, b: 57\%). (b) $300 \mathrm{~mol}$ $\%\left[\mathrm{SnCl}_{3} \mathrm{ClO}_{4}\right], \mathrm{CH}_{2} \mathrm{Cl}_{2}-\mathrm{Et}_{2} \mathrm{O}(2: 1),-30{ }^{\circ} \mathrm{C}(\mathbf{a}: 44 \%, \mathbf{b :} 43 \%)$. (c) Follow the step b in Scheme 7 (14e: 58\%, 14f: 64\%). 


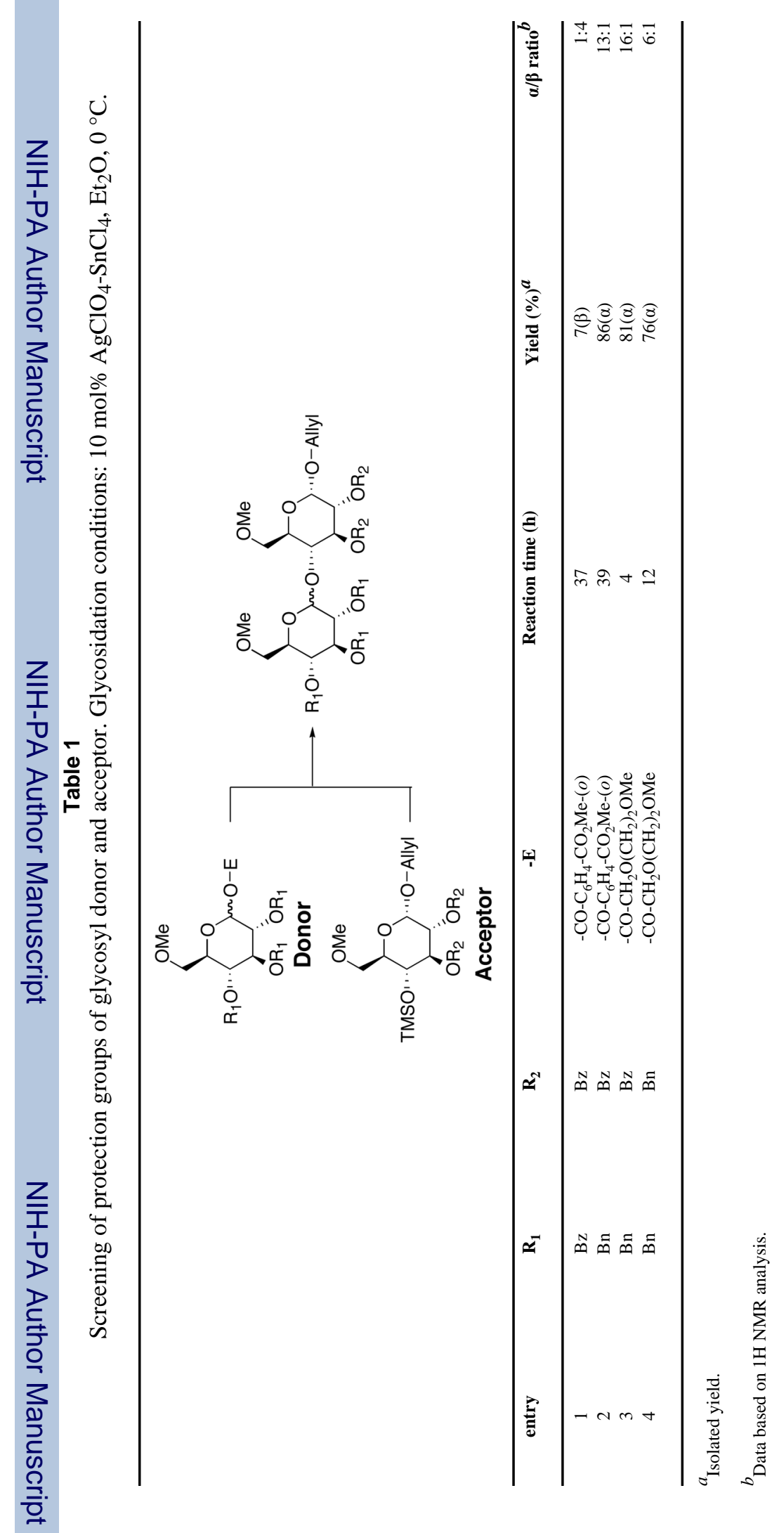




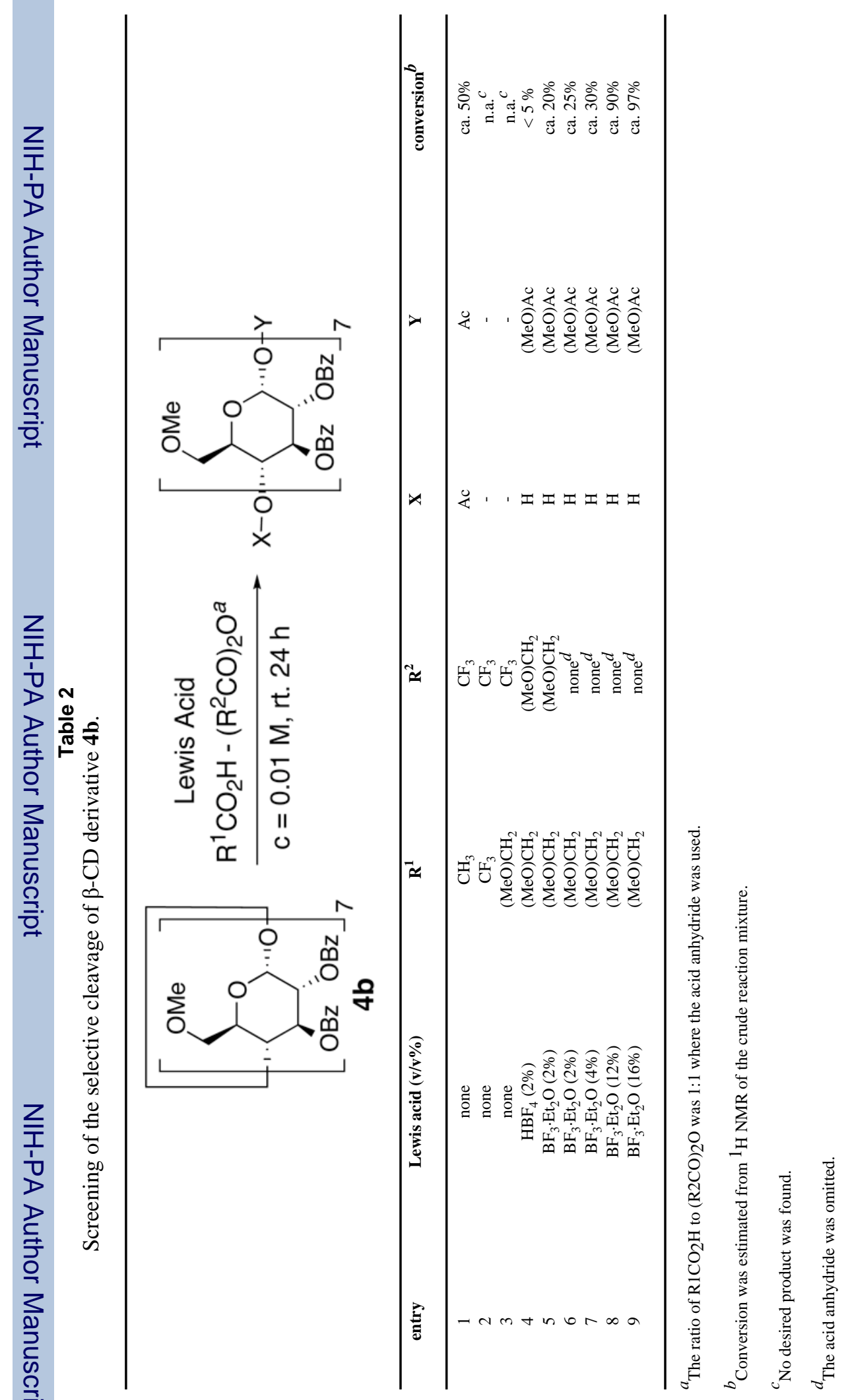




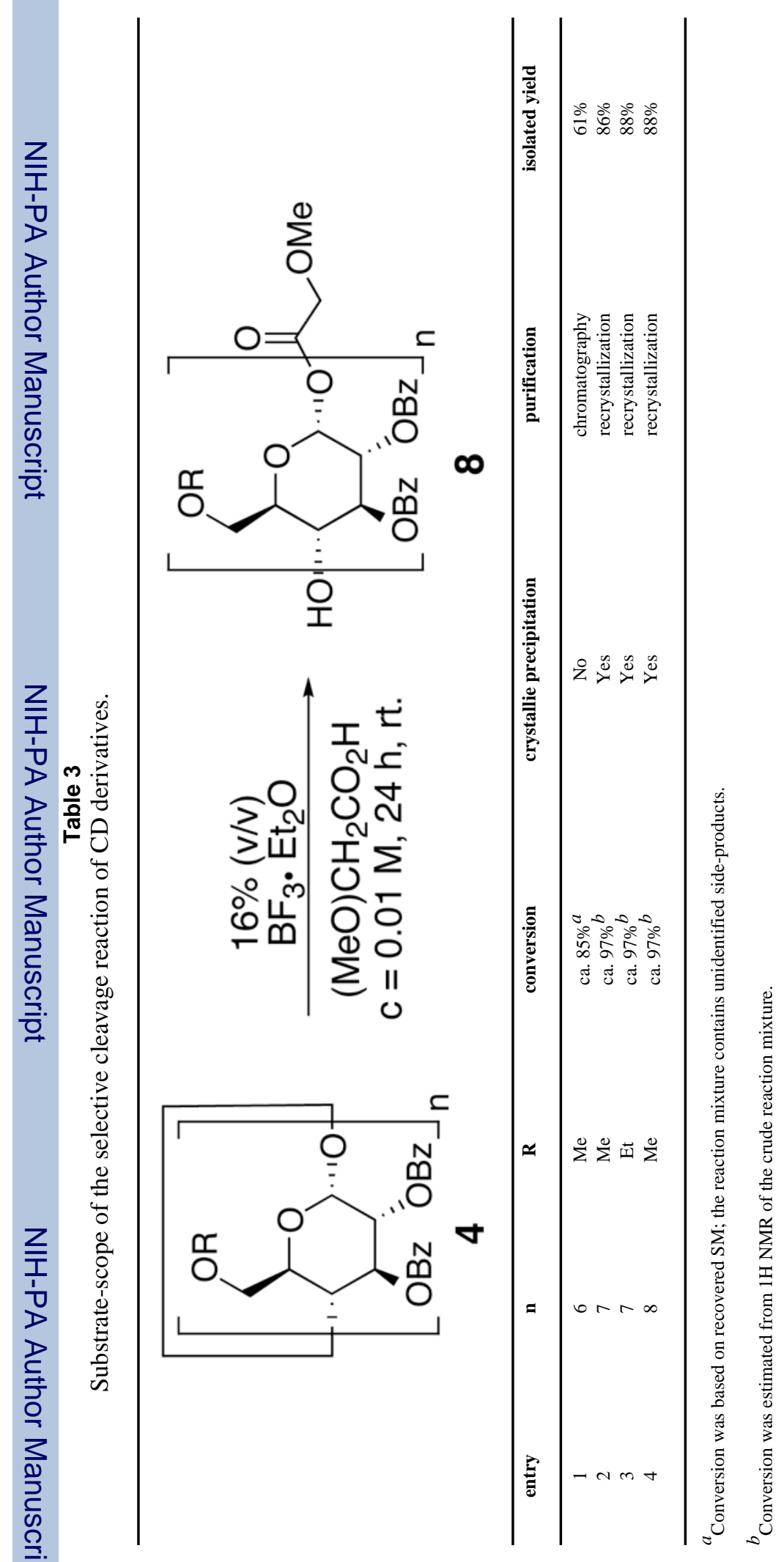



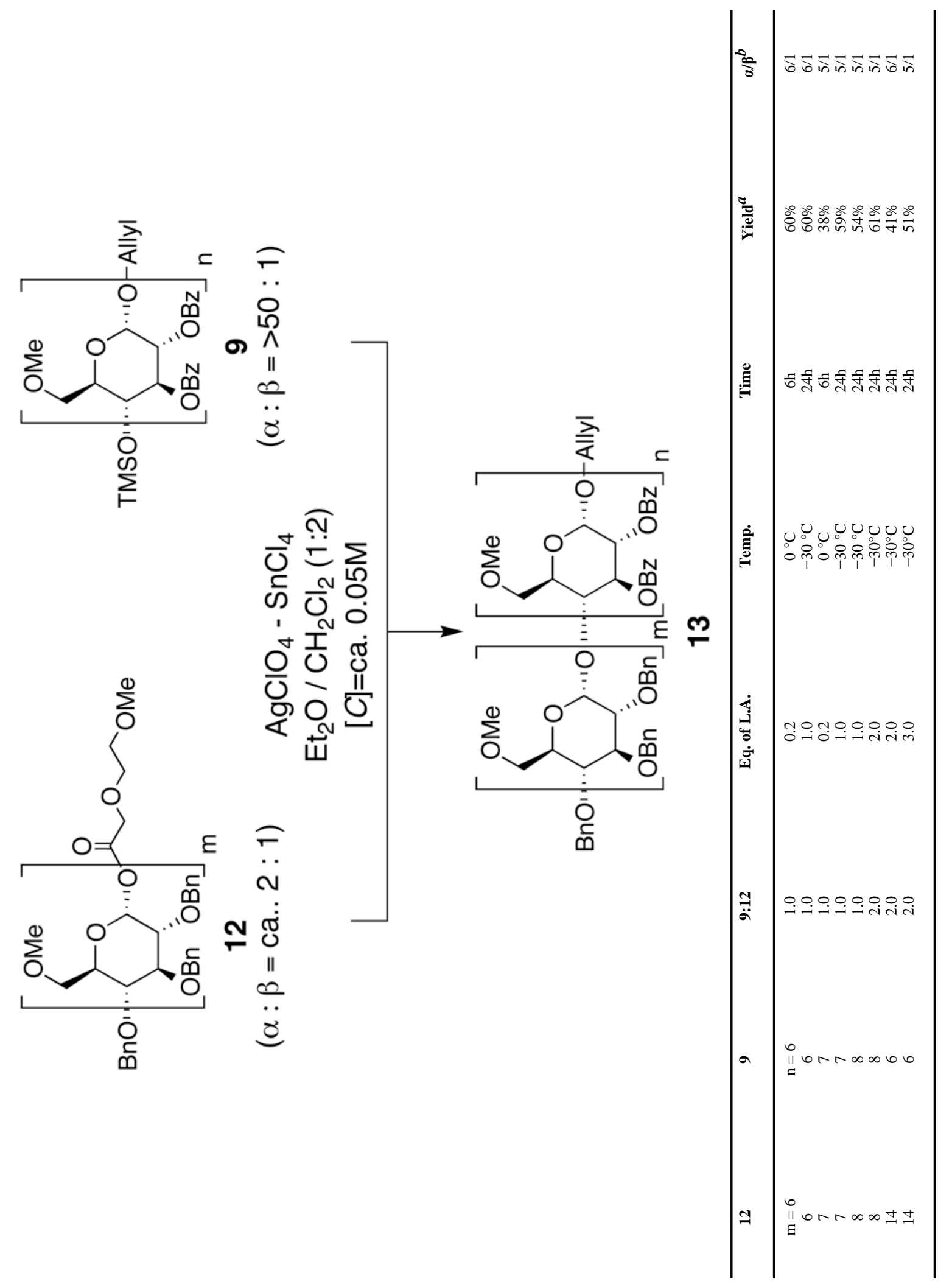

J Org Chem. Author manuscript; available in PMC 2008 August 25. 
